\title{
Post-Racial Hydraulics: The Hidden Dangers of the Universal Turn
}

\author{
Zev J. Eigen, ${ }^{*}$ Camille Gear Rich ${ }^{* *} \&$ Charlotte S. Alexander ${ }^{* * *}$
}

\begin{abstract}
In recent years, antidiscrimination scholars have focused on the productive possibilities of the "universal turn," a strategy that calls on attorneys to convert particularist claims, like race discrimination claims, into broader universalist claims that secure basic dignity, liberty, and fairness rights for all. Scholars have urged litigators to employ universalist strategies in constitutional and voting rights cases, as well as in employment litigation. Thus far, however, arguments made in favor of universalism have been largely abstract and theoretical and therefore have failed to fully consider the second order effects of universalist strategies on the ground. In this article we challenge the prevailing arguments in favor of universalism by exploring the market consequences as lawyers shift from particularist Title VII race discrimination claims to universalist Fair Labor Standards Act claims. Derived from a preliminary review of case filing statistics and qualitative data from a purposeful sample of attorney interviews, our research has uncovered forces we describe as "post-racial hydraulics," a set of non-ideological, economic, and pragmatism-based drivers produced by the trend toward universalism. We explain why "post-racial hydraulics" must be understood as key but previously unexplored factors in racial formation. Evidence suggests that, left unchecked, these non-ideological drivers will have substantive ideological effects, as they threaten to fundamentally reshape the employment litigation market and alter our understanding of race discrimination.
\end{abstract}

\footnotetext{
* The authors contributed equally to this work. Irving S. Ribicoff Visiting Associate Professor of Law, Yale Law School; Associate Professor of Law, Northwestern University School of Law.

** Professor of Law and Sociology, USC Gould School of Law.

${ }^{* * *}$ Assistant Professor of Legal Studies, J. Mack Robinson College of Business, Georgia State University; Secondary Appointment, Georgia State University College of Law. Special thanks to the editors of the STANFORD LAW REVIEW and the STANFORD JOURNAL OF CIVIL RightS AND CIVIL LIBERTIES for allowing us to present this piece at their symposium "The Civil Rights Act at 50." Many thanks also to the Duke Law School Center for Race and Inequality and the UCLA Institute for Research on Labor and Employment for workshop opportunities, as well as to attendees of the University of Michigan Ross School of Business' colloquium "Title VII: Fifty Years Later." We also thank Sam Bagenstos and Richard Epstein for helpful comments, and Gwendolyn Coleman of the Statistics Section of the Administrative Office of the U.S. Courts for her help with case filing statistics.
} 


\section{TABLE OF CONTENTS}

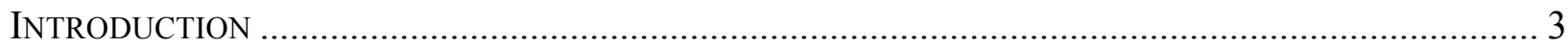

I. Post-RACIALISM AND THE LURE OF THE UNIVERSAL TURN ........................................... 8

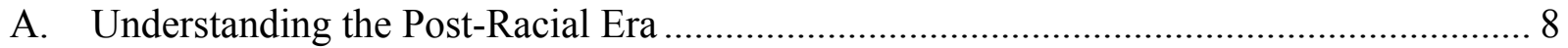

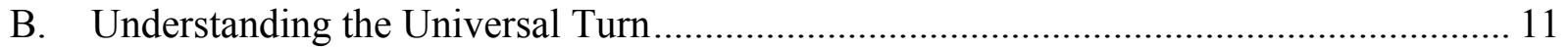

C. Understanding Post-Racial Hydraulics ............................................................... 14

II. EVIDENCE AND TheORETICAL CONTEXT For Post-Racial Hydraulics ....................... 20

A. Post-Racial Hydraulics - Origins and Methodology ….............................................. 20

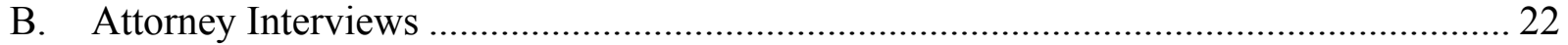

C. Post-Racial Hydraulics as Dynamics in Racial Formation ........................................... 26

III. Four Post-Racial Hydraulics: A Closer LOOK ..................................................... 29

A. The Ossification of Title VII and the Particularizing of the FLSA ............................... 29

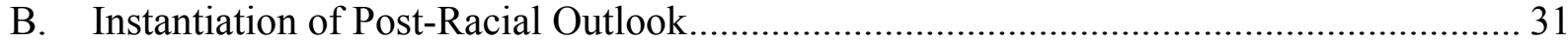

C. Access to Justice and the Redressability of Workplace Harms .................................... 32

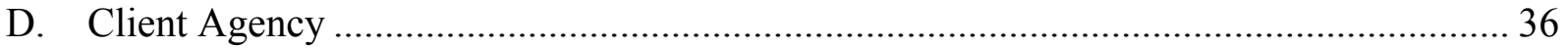

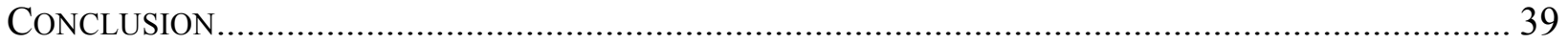

ApPendix A: Charting Shifts in EMPloyment Discrimination AND FLSA Litigation ...... 41

Appendix B: U.S. Courts Administrative Office Case Filing Data ................................ 43 


\section{Post-Racial Hydraulics: The HidDen Dangers of the Universal TurN}

\section{INTRODUCTION}

The moment a potential plaintiff enters a lawyer's office, the process of creation begins. The attorney listens to the client's winding tale of unfortunate events. She mines the client's account to find the larger justice considerations at stake, the fairness claims at the heart of the client's story, and the statutory, regulatory, and common law remedies designed to give effect to these understandings. Yet this litigation "creation story," like other creation myths, is a partial account steeped in romanticism and mystery. Lawyers are not only idealists, but pragmatists as well, and pragmatism plays a central if underappreciated role in how an attorney receives a client's story. The lawyer-pragmatist, first and foremost, considers how the story can translate into a viable litigation claim, and viability is determined by the kinds of claims she is accustomed to litigating; the stories she knows judges and juries will find sympathetic at trial; and the procedural and doctrinal hurdles that must be overcome. This pragmatism also includes the lawyer's profit-maximizing preference for cases that will cover costs and generate fees, as well those that will secure her client the highest possible recovery using the most efficient means and strategy. ${ }^{1}$ Lawyers, therefore, are not mere vessels, or conduits of information that passively present a client's case. Rather, the decisions that lawyers make — which clients to represent and which to turn away, which stories to tell and which stories to save for another day - reveal lawyers to be powerful players in shaping litigation markets.

The push and pull between idealist commitments and pragmatic considerations has always shaped lawyers' decision making processes, but the interplay between pragmatics and justice calculations has larger normative significance in lawyers' handling of employment discrimination cases, particularly in the so-called "post-racial" era. ${ }^{2}$ Increasingly, courts and the

\footnotetext{
1 This Article focuses solely on the decision making calculus and incentives that drive employment attorneys who work in for-profit firms, as opposed to attorneys who work in nonprofit organizations or government agencies. For further discussion of the pragmatic decision-making calculus lawyers use in for-profit employment law firms, see Charlotte S. Alexander, Would an Opt in Requirement Fix the Class Action Settlement? Evidence from the Fair Labor Standards Act, 80 MiSS. L.J. 443, 480 (2010) (recognizing that for-profit plaintiffs' lawyers often act as feemaximizers); see also David S. Sherwyn, Bruce Tracey \& Zev J. Eigen, In Defense of Mandatory Arbitration of Employment Disputes: Saving the Baby, Tossing out the Bath Water, and Constructing a New Sink in the Process, 2 U. PA. J. LAB. EMP. L. 73 (1999) (using modeling approach to show how plaintiffs' side employment lawyers monetize claims and choose claims based on winnability at trial as well as pretrial settleability, and noting distinctions between the two criteria). Throughout, we assume that lawyers pursue a pragmatic, profit-maximizing course in a manner consistent with their ethical obligation to act as fiduciaries and zealous advocates for their clients.

${ }^{2}$ Post-racialism is an evolving ideology that is based on the principle that in light of the significant racial progress that has been made from civil rights interventions, the state no longer needs to engage in race-based decisionmaking, nor create legal remedies based on race. Post-racialists tend to believe that most social actors do not see race as a central consideration or a critical variable that shapes life chances and daily interactions. See Camille Gear Rich, Elective Race: Recognizing Race Discrimination in the Era of Racial Self Determination, 102 GEO. L. J. 1501. 1502 (2014) (discussing how post-racialism shapes readings of race discrimination cases); Mario L. Barnes, Erwin Chemerinsky \& Trina Jones, A Post-Race Equal Protection?, 98 GEO. L.J. 967, 976 (2010) (describing post-
} 
public have begun to embrace post-racialism, the view that race discrimination is rare and race based protections are no longer necessary. In response, many pragmatic attorneys are adopting the "universal turn, ${ }^{3}$ a litigation strategy that involves replacing particularist race discrimination claims with race-neutral universalist claims that guarantee basic dignity, liberty, and fairness rights for all covered persons. Pragmatists tend to value universalist claims because they are based on simpler legal inquiries than particularist claims (they do not require thorny proof of discriminatory intent) ${ }^{4}$; relatedly, they offer cheaper and faster discovery; and they are comparatively more winnable because they do not risk triggering judges' and juries' post-racial bias. Proponents of universalist litigation strategies suggest that this shift merely changes the number of court cases filed under different statutory rubrics. They imagine a world in which race discrimination claims neatly convert into universalist claims centering on family leave rights, ${ }^{5}$ generalized fair treatment mandates, ${ }^{6}$ and healthy workplace requirements. ${ }^{7}$ We theorize, however, that the dynamics set in motion by the universal turn will be far more complicated, for our research has revealed a series of second order drivers in the employment litigation market, what we call "post-racial hydraulics," that are set in motion by the shift to universalist claims. These hydraulics, collectively and over time, threaten to fundamentally change the employment litigation market and employment discrimination doctrine, as well as shape lay persons' and judges' views about race discrimination as a social problem.

We describe the forces triggered by the universal turn as "post-racial hydraulics" because they are the predictable, if unanticipated effect of litigators' abandonment of particularist race discrimination claims in favor of universalist claims under other employment fairness statutes. ${ }^{8}$ Our theory is based on observations we generated by operationalizing the universal turn in

racialism in more general terms); Sumi Cho, Post-Racialism, 94 IowA L. REV. 1589, 1601 (2009) (same). For further discussion, see Section I.A.

${ }^{3}$ The "universal turn" is a term coined to describe the wave of litigation and policy arguments that attempt to address race and gender inequality issues by offering "universal" race and gender-neutral solutions. As Professor Jessica Clarke explains, these universal arguments "shift[] focus from equal rights [arguments] to [arguments about] universal rights like liberty or dignity.” Jessica A. Clarke, Beyond Equality? Against the Universal Turn in Workplace Protections, 86 IND. L.J. 1219, 1221 (2011). Various scholars have explored universalist arguments over the past ten years including Kenji Yoshino, Sam Bagenstos, Martha Fineman, and Vicki Schultz. For a discussion of scholars' arguments on universalism, see notes 11-12 and accompanying text.

${ }^{4}$ Indeed, discrimination may take on more subtle forms today and claims may consequently be more difficult to prove than when status based statutes were enacted given employers' increased awareness that overt discrimination is illegal and in many instances socially unacceptable. Susan Sturm, Second Generation Employment

Discrimination: A Structural Approach, 101 CoLUM. L. REV. 458, 460-61 (2001) (observing that "smoking gun" evidence of discrimination has been replaced by subtler forms of discrimination that may be harder to prove in court).

${ }^{5}$ Clarke, supra note 3 at 1233; Katie R. Eyer, That's Not Discrimination: American Beliefs and the Limits of AntiDiscrimination Law, 96 MINN. L. REV. 1275, 1343 (2012) (discussing universalist family leave rights).

${ }^{6}$ Eyer, supra note 5 at 1344 (discussing common law claims for wrongful discharge).

${ }^{7}$ Id. (discussing healthy workplace laws).

${ }^{8}$ Ben Sachs has used similar "hydraulic" imagery in his discussion of the interplay between labor and employment law. Benjamin I. Sachs, Employment Law As Labor Law, 29 CARDOZO L. REV. 2685, 2687 (2008) ("Because workers, unions, and certain employers continue to demand collective organization and interaction, this blockage [in the labor law system due to National Labor Relations Act dysfunction] has led not to 'ossification' but to a hydraulic effect: unable to find an outlet through the NLRA, the pressure from this continuing demand for collective action has forced open alternative legal channels."). 
employment cases, as well real world qualitative data from plaintiffs' lawyers who have shifted from claims brought under particularist employment discrimination statutes such as Title VII of the Civil Rights Act of 1964, to universalist claims under the wage and hour protections found in the Fair Labor Standards Act ("FLSA"). ${ }^{9}$

While our research is at an early stage, we have identified four side-effects of universalism that will affect the employment litigation market in the long term. First, Title VII race discrimination doctrine will ossify; the legal definition of discrimination will stagnate due to a lack of litigation that stretches its contours. Ultimately, the statute will become unresponsive to contemporary discrimination patterns. ${ }^{10}$ Second, the paucity of race discrimination litigation will bolster the courts' and the public's post-racial view that racism is a rare phenomenon. Third, as plaintiffs' attorneys' shift their employment law practice away from Title VII particularist claims to handle FLSA universalist claims, they will reduce plaintiffs' access to justice and the overall redressability of workplace harms, particularly for low-wage workers. Plaintiffs who want to file Title VII race discrimination claims will find that there are far fewer lawyers willing to assist them. Also, the universalist FLSA claims offered to discrimination plaintiffs will be underinclusive in critical ways, and therefore will function as poor substitutes for more comprehensive discrimination statutes. This observation is critical: there will be a class of plaintiffs who are discriminated against but who are not wronged under wage and hour statutes and they will lose de facto legal protection, even while retaining de jure protection. Fourth, race discrimination plaintiffs who do find lawyers willing to take their cases may find that they are being pressured to change the way they understand and represent their injuries, raising concerns about client agency and voice.

Our identification and discussion of these post-racial hydraulics is significant in two ways. First, this Article promises to be a key intervention in current debates about the value of universalism. As antidiscrimination scholars know, "the universal turn" has been a central theme in civil rights scholars' work for more than a decade. ${ }^{11}$ Advocates of the universal turn have praised the approach for its strategic and normative benefits, but typically frame discussion of

\footnotetext{
${ }^{9}$ See Section II.B, infra, and accompanying text, discussing interviews with fifteen experienced employment litigators regarding their shifting of claims between the particularist Title VII and universalist FLSA.

${ }^{10}$ Cf. Cynthia L. Estlund, The Ossification of American Labor Law, 102 CoLUM. L. REV. 1527, 1531 (2002) (using the term "ossification" to describe the inability of American labor law to respond effectively "to the very different economic and social conditions that workers and employers face today"); Sachs, supra note 8 at 2686 (discussing view that labor law has "ossified" and is no longer responsive to contemporary labor movement needs).

${ }^{11}$ For example, voting rights scholars have argued that universalist statutes would be more effective at securing voting rights for minorities than particularist claims that seek to address discrimination against particular protected class groups. See Samuel Issacharoff's Beyond the Discrimination Model on Voting, 127 HARV. L. REV. 95 (2013); (arguing universalist voters right protections might better achieve racial equality goals than more particularist voting rights legislation; Richard H. Pildes, The Future of Voting Rights Policy: From Anti-Discrimination to the Right to Vote, 49 How. L.J. 741 (2006) (same); Richard L. Hasen, Race or Party?: How Courts Should Think About Republican Efforts to Make it Harder to Vote in North Carolina and Elsewhere, 127 HARV. L. REV. F. 58 (2014) (same); Daniel P. Tokaji, Responding to Shelby County: A Grand Election Bargain, 8 HARV. L.\& POL'Y REV. 71 (2014) (same).
} 
these issues at a relatively high level of abstraction. ${ }^{12}$ Critics of universalism have offered largely theoretical work as well, as scholars tend to focus on the conceptual and normative dangers that the switch to universalism poses. ${ }^{13}$ This article is the first to theorize about what happens when universalism is operationalized by litigators, to assess what happens when universalist arguments are transported from academic discussions and become norms that shape the employment litigation market itself. In order to ensure that our insights were well grounded in the pragmatics and economic drivers that accompany mass adoption of universalism, we mined comments from practicing litigators to test our concerns, focusing on the transition in employment litigation markets from Title VII race discrimination claims to universalist FLSA wage and hour claims. ${ }^{14}$

${ }^{12}$ Many prominent scholars who historically have worked on particularist employment discrimination claims have
also offered arguments in praise of universalist strategies; however, most scholars writing on this issue discuss
universalism in general terms, either stressing its normative or policy-based advantages or, relatedly, its workplace
culture effects. Samuel R. Bagenstos, Employment Law and Social Equality, 112 MiCH. L. REV. 225 (2013) (arguing that universal provisions of employment law can serve equality interests); Martha Albertson Fineman, The Vulnerable Subject: Anchoring Equality in the Human Condition, 20 YALE J.L. \& FeMINISM 1, 21 (2008) (arguing in favor of universalism because "the shared, universal nature of vulnerability draws the whole of society-not just a defined minority-under scrutiny . . . and therefore is a 'post-identity' analysis of what sort of protection society owes its members."); Vicki Schultz \& Allison Hoffman, The Need for a Reduced Workweek in the United States, in Precarious Work, Women and the New Economy: The Challenge to Legal Norms 131, 133 (Judy Fudge \& Rosemary Owens eds., 2006) (arguing that universal measures like the shorter workweek prove that "equality for women can best be achieved through [strategies] that benefit all workers"); Catherine L. Fisk, Humiliation at Work, 8 WM. \& MARY J. WOMEN \& L. 73, 95 (2001) ("The development of a [universalist] jurisprudence of workplace respect for all persons is the unfinished business of the project of feminist jurisprudence."). See also Rachel ArnowRichman, Incenting Flexibility: The Relationship Between Public Law and Voluntary Action in Enhancing Work/Life Balance, 42 CONN. L. REV. 1081, 1108-12 (2010) (arguing consistent with universalism that all employees, not just the disabled, should have a right to request workplace accommodations and receive a written response from their employer); Catherine Albiston, Institutional Inequality, 2009 WIS. L. REV. 1093 (arguing that the universalist protections of the Family Medical Leave Act will better address workplace inequality than particularist gender discrimination claims under Title VII and the Pregnancy Discrimination Act); Ann C. McGinley, Rethinking Civil Rights and Employment at Will: Toward a Coherent National Discharge Policy, 57 Оніо Sт. L.J. 1443 (1996) (arguing civil rights ends can be reached by universalist just-cause termination standards). Arguments in the constitutional arena tend to take on the highest level of abstraction, as compared to discussions in other areas of Civil Rights law. For example see Kenji Yoshino, Covering: THE HIDDEn Assault On OuR CiviL RIGHTS 192 (2006) (arguing in favor of liberty equality and dignity arguments in constitutional cases rather than potentially essentializing claims based on race, sexual orientation or sex). See also Kenji Yoshino, The New Equal Protection, 12 HARV. L. REV. 747, 749 (2011) (refining this argument to provisionally advocate a shift in equal protection jurisprudence by the Court towards acknowledgement of the "links between liberty and equality," with an emphasis on liberty).

${ }^{13}$ Clarke, supra note 3 at 1221 . While Bagenstos is described as a "critic" of universalism here, he has also made universalist arguments, but has more recently stepped back to critically assess both the benefits and problems associated with the universal turn. See, e.g., SAMUEL R. BAGENStos, LAW AND the CONTRADictions Of THE DisABILITY RIGHTS MOVEMENT 51-54, 145 (2009) (advocating universal health insurance and universal workplace accommodation requirements to address problems of disability inequality). $C f$. Samuel R. Bagenstos, Universalism and Civil Rights (With Notes on Voting Rights After Shelby), 123 YALE L.J. 2838, 2876 (2014) (cataloguing and assessing the benefits and the costs associated with the trend towards universalism)

${ }^{14}$ Our methodology is described in greater detail in Sections II.A and B. In short, our focus on the specific hydraulic relationship between Title VII and FLSA claims stems from Eigen's observations of the shift between claim types during his work as an expert in employment cases, as well as Alexander's observation that the number of FLSA cases filed over the past several decades in federal court has co-occurred with a drop in Title VII case 
The Article makes a second contribution by revealing new important insights about dynamics in "racial formation." The study of racial formation is an analytical framework drawn from the sociological literature by antidiscrimination scholars to map shifts in social and legal discourse about race. ${ }^{15}$ The insights we provide here will assist both sociologists and legal scholars in discussing the role that law plays in "racial projects" and in racial formation more generally as we, for the first time, reveal how non-ideological pragmatic factors and marketbased concerns can drive the racial formation process. These pragmatics and market calculations work as macro-level factors but also have "trickle down" effects and therefore work as microdynamics as well, when lawyers interact with their clients. ${ }^{16}$

The Article proceeds as follows. Part I, Section A defines post-racialism and describes its connection to the growing judicial hostility toward employment discrimination claims. Part B then addresses scholars' solution for post-racialism, the "universal turn," and for the first time explicitly frames universalism as a potentially problematic but practical response to postracialism. Part $\mathrm{C}$ introduces our theory of post-racial hydraulics, using a case study to reveal the gaps and pressures created when lawyers map FLSA claims over Title VII race discrimination claims. Part II, Sections A and B provide early evidence of post-racial hydraulics from a purposeful sample of fifteen experienced employment litigators we interviewed. Interviewees were asked about their views of the viability of particularist Title VII race discrimination claims versus universalist FLSA claims and their own observations of the second order drivers that we call post-racial hydraulics. Section $C$ provides theoretical context for understanding the significance of these drivers, revealing their role as powerful (and thus far undisclosed) factors in the racial formation process. Section $\mathrm{C}$ also explains why lawyers' non-ideological pragmatic calculations in the case selection and case-presentation process will effectively instantiate postracialism.

Part III then engages in a closer examination of each of the four post-racial hydraulics we identify, and their long term consequences. These dynamics are: (1) the ossification of Title VII doctrine; (2) the stale nature of social understandings about discrimination; (3) issues of access to justice and redressability of workplace harms; and (4) concerns about client agency and voice. All of these dynamics will be explored in more detail in future empirical work. The final Part concludes.

\footnotetext{
filings. Appendices A and B set out the case filing data that show these trends. See also Charlotte S. Alexander, An Empirical Portrait of Federal Wage and Hour Litigation (work in progress; draft available from author). To investigate further, we selected a "purposeful" or "judgment" sample of fifteen senior, experienced employment discrimination lawyers to interview who had worked on both Title VII discrimination claims and Fair Labor Standards Act claims, and interviewed them about their claims-shifting practices. See notes 87-94, infra, and accompanying text.

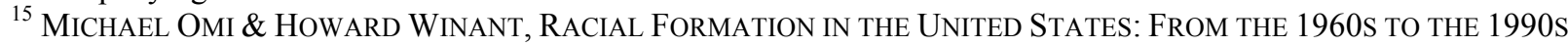
60-61 (2d ed. 1994); Howard Winant, RACIAL Conditions: PolitiCs, THEORY, COMPARISONS 23-25 (1994). See also Rich, supra note 2 at 1509-1510 (exploring the relevance of the distinction between micro and macro analyses in the study of racial formation or racial projects).

${ }^{16}$ See Rich, supra note 2 at 1508-09 (discussing the distinction between macro and micro analyses in racial formation).
} 


\section{Post-Racialism AND THE LURE OF THE UNIVERSAL TURN}

A. Understanding the Post-Racial Era

Much ink has been spilled over the advent of the post-racial era, but this discussion has often occurred in the absence of any clear definition of what "post-racialism" means. The Oxford Dictionary describes post-racialism as referring to a "period or society in which racial prejudice and discrimination no longer exist." 17 Antidiscrimination scholars offer more nuanced definitions that highlight post-racialism's role as an aspirational vision or, variously, as a powerful, seductive but dangerous misdescription with profound political consequences. For example, Mario Barnes, Erwin Chermerinsky and Trina Jones stress post-racialism's multiple nature, explaining that it is "a set of beliefs that coalesce to posit that racial discrimination is rare and aberrant behavior as evidenced by America's and Americans' pronounced racial progress."18 Key to post-racialism is "the belief that governments - both state and federal - should not consider race in their decision making"19; this belief can result in a "retreat from race" by the courts in discrimination cases. ${ }^{20}$

Sumi Cho attempts to place post-racialism in historical context. As Cho explains, postracialism is a modern update on the colorblindness discourse that dominated the 1980s and 1990s and that was used to support calls for race neutrality and the abolition of race-based affirmative action. ${ }^{21}$ However, rather than being "merely a political trend or phenomenon or social fact," she explains, post-racialism is an evolving "twenty-first-century ideology that reflects a belief that due to the significant racial progress that has been made, the state need not engage in race-based decision-making or adopt race-based remedies, and [further] that civil society should eschew race as a central organizing principle of social action." 22 Cho explains that the post-racial ethos has four central features: (1) the theme of racial progress or transcendence; (2) the belief that race neutral universal tools are the best way to address social problems; (3) the proposition that all references to race are inappropriate, whether they are articulated by racially biased parties or by parties interested in facilitating antidiscrimination efforts and (4) a distancing move - the individual's desire to show that her refusal to discuss race is not based on what scholars call "dominative" racism. ${ }^{23}$ Cho explains that, while all four beliefs are not required to establish that

\footnotetext{
${ }^{17}$ Oxford Dictionaries, available at http://www.oxforddictionaries.com/us.

${ }^{18}$ Barnes, et al., supra note 2 at 968 (defining post-racialism as "a set of beliefs that coalesce to posit that racial discrimination is rare and aberrant behavior as evidenced by America's and Americans' pronounced racial progress").

${ }^{19}$ Cho, supra note 2 at 1594.

${ }^{20}$ Barnes, et al., supra note 2 at 971 ("[The U.S. Supreme] Court's retreat from race began at least as early as Regents of the University of California v. Bakke."); Cho, supra note 2 at 1594 ("According to post-racial logic, the move is to effectuate a "retreat from race.") (borrowing the term "retreat from race" from DANA Y. TAKAGI, THE RETREAT FROM RACE: ASIAN-AMERICAN ADMISSIONS AND RACIAL POLITICS (1993)).

${ }^{21}$ Cho, supra note 2 at $1593 ; \mathrm{i} d$. at $1597-99$.

${ }^{22}$ Id. at 1593 (giving the example of "electoral campaigns where 'strategic universalism' is a virtual necessity").

23 Adam R. Pearson, et al., The Nature of Contemporary Prejudice: Insights from Aversive Racism, 3 SoCIAL AND PeRsonAlity PSYCHOLOGICAL COMPASS 1, 3 (2009). Dominative racism is the "traditional, blatant form of racial bias." The dominative racist is the "type who acts out bigoted beliefs - he represents the open flame of racial hatred." Id.
} 
something fits within a post-racial ethos, the four themes are "central and common components of post-racialist ideology and discourse." ${ }^{24}$ Cho further worries about post-racialism's broad allure, noting that it appeals to people on both the Right and the Left by denying the continued importance of race and minimizing the continued occurrence of race discrimination. As a result, post-racialism can dangerously "limit the acceptable political discourse for racial equality . . . and constrain the effectiveness of racial justice movements." 25

Numerous other legal scholars have warned about the growing persuasive power of postracialism and introduced terminology to facilitate discussion about post-racial subjects' preoccupations and concerns. Most of the terms scholars offer focus on post-racial subjects' psychological exhaustion and racial anxiety; these include "equality fatigue," 26 "racial exhaustion," 27 "racial reticence," 28 and "racial fatigue." 29 All of the terms share one central understanding: Americans evince a strong commitment to equality, but they are often deeply uncomfortable talking about how race discrimination shapes their daily lives. ${ }^{30}$ Of course, not all persons who experience racial anxiety engage in race discrimination. However, when the racially anxious do discriminate, their bias can take the form of "aversive racism." 31 Persons suffering from aversive racism "sympathize with victims of past injustice, support principles of racial equality, and genuinely regard themselves as non-prejudiced, but at the same time possess conflicting, often non-conscious, negative feelings and beliefs about Blacks [and other minorities] that are rooted in basic psychological processes that promote racial bias." 32 Indeed, aversive racists' very self esteem depends on their ability to maintain the view that they are not racially biased, so they find ways to express racial bias using seemingly neutral, generally applicable policies and procedures. ${ }^{33}$ Moreover, because aversive racists are invested in not

\footnotetext{
${ }^{24}$ Cho, supra note 2 at 1600.

${ }^{25}$ Id. at 1593 .

${ }^{26}$ Yoshino, supra note 12 at 794 (discussing equality fatigue).

${ }^{27}$ Darren Lenard Hutchinson, Racial Exhaustion, 86 WASH. U. L. REV. 917, 922 (2009) ("This Article examines historical and contemporary race discourse contained in political and juridical sources in order to illustrate how opponents to racial egalitarian measures have 0 frequently contested such policies on the grounds that they are redundant, unnecessary, or too burdensome or taxing. Racial exhaustion rhetoric has operated as a persistent discursive instrument utilized to contest claims of racial injustice and to resist the enactment of racial egalitarian legislation.").

${ }^{28}$ Camille Gear Rich, Decline to State: Diversity Talk and the American Law Student, 18 S. CAL. REV. L. \& Soc. JUST. 539, 564 (2009) ("In order to avoid having to perpetually police and re-evaluate their own conduct, racially fatigued students simply avoid people of color and discussion of racial issues. Perhaps most ironic, racially fatigued students engage in these avoidance strategies precisely because they identify as socially progressive, anti-racist persons. Some racially fatigued students are simply afraid of participating in conversations, because they believe that one insensitive or impolitic comment could result in them being branded as racist. Others simply want to avoid self reflection. These feelings result in what I refer to as 'racial reticence' - racially fatigued persons' attempts to avoid racial conversations for fear of making a bad turn.").

${ }^{29} I d$.

${ }^{30} \mathrm{Id}$.

${ }^{31}$ Pearson, et al., supra note 23 (discussing aversive racism).

${ }^{32} I d$. at 3 .

${ }^{33} \mathrm{Id}$. at 8 (explaining that "when persons suffering from aversive racism are presented with a situation in which the normative response is clear (e.g., right and wrong are clearly defined), aversive racists will not discriminate against Blacks. In these contexts, aversive racists will be especially motivated to avoid feelings,
} 
seeing their own discrimination, they are for the most part reluctant to cast judgment on other parties' conduct. As Katie Eyer observes, over a wide array of factual circumstances - ranging from traditional disparate treatment to more complex forms of bias-scholars have found that most people do not "see" discrimination, except where there is effectively no plausible alternative."34

Scholars note that the judiciary appears to have adopted a post-racial ethos as well. As Vicki Schultz and Stephen Petterson explain, "After a decade of efforts to enforce Title VII, federal judges apparently began to share the general public's belief that employment discrimination against minorities had been largely eradicated." 35 Trina Jones agrees, noting that race discrimination plaintiffs now have an uphill battle with both judges and juries in the postracial era. "Because ... [discrimination] claims are premised on the continuing presence of racism, they are now counter to society's normative beliefs" ${ }^{36}$ and therefore more difficult to win. In a piece criticizing the judiciary for overusing summary judgment in employment discrimination cases, Judge Mark Bennett provides further evidence of the judiciary's adoption of post-racial views. ${ }^{37}$ After noting that civil rights statutes have eradicated most workplace discrimination and that workplace discrimination is now "rare," he further explains that many of the employment discrimination claims judges see at present are not meritorious. Rather, he explains, they tend to involve bad employees attempting to find some way to coerce their employers into retaining them. ${ }^{38}$ Ironically, Judge Bennett's essay is intended to function as a plea for judges to engage in more careful consideration of discrimination plaintiffs' claims. However, the comments Judge Bennett makes in the course of the discussion reveal the very assumptions judges hold that make it difficult for discrimination plaintiffs to prevail. Judge Bennett also observes that contemporary discrimination is "more subtle" and this may be why judges are ruling for employers disproportionately in employment discrimination cases. ${ }^{39}$ Taken

\footnotetext{
beliefs, and behaviors that could be associated with racist intent. However, the non-conscious feelings and beliefs that aversive racists also possess will produce discrimination in situations in which normative structure is weak, when the guidelines for appropriate behavior are unclear, when the basis for social judgment is vague, or when one's actions can be justified or rationalized on the basis of some factor other than race.").

${ }^{34}$ Eyer, supra note 5 at 1341 (2012) (summarizing sociology and psychological literature).

${ }^{35}$ Vicki Schultz \& Stephen Petterson, Race, Gender, Work, and Choice: An Empirical Study of the Lack of Interest Defense in Title VII Cases Challenging Job Segregation, 59 U. CHI. L. REV. 1073, 1180 (1992).

${ }^{36}$ Trina Jones, Anti-Discrimination Law in Peril?, 75 Mo. L. REV. 423, 433 (2010). Jones also notes that "[i]f judges believe that discrimination is rare and aberrant, they perceive no need to probe deeply an employer's justifications, even when those justifications are specious and proved false." $I d$. Instead, the burden shifts to "plaintiffs to come forth with additional proof to counter the colorblind, post-racial presumption." Id. She further argues, "this presumption is not supplied by law and is counter to 400 years of U.S. history and abundant evidence of continuing racial inequality." Id.

${ }^{37}$ Mark W. Bennett, No Spittin,' No Cussin,' and No Summary Judgment Days of Employment Discrimination Litigation to The Defendant's Summary Judgment Affirmed Without Comment Days: One Judge's Four Decade Perspective, 57 N.Y.L. SCH. L. REV. 685 (2012-2013).

${ }^{38}$ Id. at 697-98.

${ }^{39} I d$. at 705 ("In my view, while employers discriminate less today than decades ago, when they do discriminate, it is in more subtle ways."); see also Nancy Gertner, The Judicial Repeal of the Johnson/Kennedy Administration's 'Signature' Achievement (March 9, 2014). Available at SSRN: http://ssrn.com/abstract=2406671 (describing the forces that cause Title VII claims to fare badly in federal courts, including judges' beliefs that discrimination no longer occurs, meritless discrimination filings, the filing of more meritorious cases in state court to take advantage
} 
together, all of these factors suggest that Title VII plaintiffs face special challenges. Indeed, empirical studies show that employment discrimination plaintiffs fare less well than plaintiffs in other categories of litigation, ${ }^{40}$ as well as when compared against plaintiffs in litigation more generally. ${ }^{41}$

\section{B. Understanding the Universal Turn}

In response to the rising tide of post-racial skepticism about civil rights claims, some scholars have argued that plaintiffs' lawyers should, when possible, reframe race discrimination claims as race-neutral dignity, fairness and liberty claims. These scholars call on lawyers to adopt what Jessica Clarke calls the "universal turn" as a litigation strategy. ${ }^{42}$ Universalist claims guarantee a minimum floor of rights or benefits for all persons, or at least guarantee a set of rights or benefits to a broad group of people not defined according to identity axes. Sam Bagenstos notes that what is "crucial to the definition [of universalism] is the idea that we can determine an individual's entitlement without considering identity groups at all."43 Clarke similarly explains that "the new universalism endeavors to draw attention to problems once seen as issues of inequality without recourse to identity categories. " 44 This version of universalism

of more worker friendly state laws, employer-friendly Supreme Court decisions that have narrowed Title VII doctrine, and case management pressures on judges that cause them to dispose of Title VII cases on procedural grounds without getting to the merits).

${ }^{40}$ Kevin Clermont and Stewart Schwab have demonstrated that when compared to plaintiffs in other types of cases, employment discrimination plaintiffs "manage fewer resolutions early in litigation, and so they have to proceed to trial more often"; win less frequently at pretrial stages and at trial; experience appeals more often even when they do win below; and, on appeal, "have a harder time both in preserving their successes and in reversing adverse outcomes." Kevin Clermont \& Stewart Schwab, Employment Discrimination Cases in Federal Courts: From Bad to Worse, 3 Harv. L. \& Pol'Y Rev. 103, 132 (2009); Kevin M. Clermont \& Stewart J. Schwab, How Employment Discrimination Plaintiffs Fare in Federal Court, 1 J. EmPIRICAl Legal STUD. 429 (2004); Kevin M. Clermont et al., How Employment-Discrimination Plaintiffs Fare in the Federal Courts of Appeals, 7 EMP. RTS. \& EMP. POL'Y J. 547 (2003); see also John J. Donohue III \& Peter Siegelman, The Changing Nature of Employment Discrimination Litigation, 43 STAN. L. REV. 983 (1991) John J. Donohue III \& Peter Siegelman, The Evolution of Employment Discrimination Law in the 1990s: A Preliminary Empirical Investigation, in HANDBOOK OF EMPLOYMENT DisCRIMINATION RESEARCH: RightS AND REALITIES 261 (Laura Beth Nielsen \& Robert L. Nelson eds., 2005); see also Eyer, supra note $5 \mathrm{n} .27$ (collecting numerous studies on case outcomes).

${ }^{41}$ Laura Beth Nielsen, Robert Nelson, and Ryon Lancaster offer similarly discouraging news about employment discrimination plaintiffs' prospects in federal court. Laura Beth Nielsen, Robert L. Nelson \& Ryon Lancaster, Individual Justice or Collective Legal Mobilization? Employment Discrimination Litigation in the Post Civil Rights United States, 7 J. EMP. LEG. STUD. 175, 176 (2010). In a 2010 study, the authors analyzed the outcomes of a random sample of employment discrimination lawsuits filed in seven federal district courts during the five year period from 1988 to 2003. Nineteen percent of the cases in their sample ended in dismissal and fifty percent in early settlement, defined as settlement before the filing of a motion for summary judgment. Of the cases that did not settle early, in fifty-seven percent of cases the plaintiffs ultimately lost at summary judgment; of the cases that survived summary judgment, forty-three percent proceeded to trial, where plaintiffs won "33 percent of the time, or in [only] 2 percent of filings overall." It is important to note, however, that these studies do not demonstrate judicial predisposition or hostility against employee-plaintiffs. Rather, their findings are merely consistent with that theory. Id. at 181 (describing methodology).

${ }^{42}$ Eyer, supra note 5 at 1341 (promoting adoption of "[e]xtra-discrimination remedies (EDRs). . . that in some way address questions of discrimination (or that allow a putative victim of discrimination to challenge a discriminatory job action), but that do not ask the liability question of 'discrimination"”).

${ }^{43}$ Bagenstos, supra note 13 at 2842.

${ }^{44}$ Clarke, supra note 3 at 1240. 
"chang[es] the axis of protection from identity traits to universal conditions like vulnerability ... and shifts emphasis from equal rights [arguments] to [arguments about] universal rights like liberty or dignity. Additionally, universalism moves us away from 'condemnation of prejudice' and instead emphasizes the need to "ban disrespect or irrational decision making. " 45 Clarke suggests that proponents of universal strategies may be taking their cue from European nations, which tend to rely on broad dignity and liberty rights to protect their citizens. ${ }^{46}$

Bagenstos provides a useful account of universalism's strengths. First, he explains, universalism is tactically advantageous, as it secures political support for laws that promote civil rights interests and broader judicial implementation of these laws. In simpler terms, civil rights claims promoted under a universal statute find broad support and resist political backlash. ${ }^{47}$ Clarke agrees, noting that the primary appeal of universal rights claims is that litigators avoid public resentment based on the view that "special rights" are being created for racial minorities. ${ }^{48}$ Second, Bagenstos explains, universal claims have substantive advantages because they aggressively attack the structures that lead to inequality, rather than focusing on race and identity axes. Third, universal claims have expressive and symbolic value. These claims avoid essentializing identity characteristics and instead emphasize human commonality across groups. ${ }^{49}$ Clarke concurs, noting that "universalist claims avoid essentialism problems, moving away from raced notions of 'equality' to general norms based on civility, dignity, liberty, and citizenship." 50

While the account of universalism that Clarke and Bagenstos offer is helpful, some would argue that they do not challenge universalism's supporters sufficiently, as all of the "virtues" of universalism they describe are premised on fully accommodating or acquiescing to post-racial understandings. To be clear, both Clarke and Bagenstos are calling on scholars for a more precise accounting of the costs and benefits of universalism. However, in describing universalism's supposed benefits, they do not acknowledge that universalists are in colloquial terms, "taking the easy way out." Supporters of universalism stress universalism's ability to harness and build on the post-racial view that race is unimportant and the belief that discrimination constructs are not a useful way for understanding social conflict. This work is in

\footnotetext{
${ }^{45} I d$.

${ }^{46}$ Id. at $1231-32$.

${ }^{47}$ Bagenstos, supra note 13 at 2848-2851.

${ }^{48}$ Clarke, supra note 3 at 1222-23.

${ }^{49}$ Bagenstos, supra note 13 at 2864 (citing Yoshino, supra note 12 at 795); see also Leticia M. Saucedo, Addressing Segregation in the Brown Collar Workplace: Toward a Solution for the Inexorable 100\%, 41 MICH. J. L. REFORM 447 (2008) (discussing universalist strategies for coalition-building among social groups); Noah Zatz, Beyond the Zero-Sum Game: Toward Title VII Protection for Intergroup Solidarity, 77 IND. L.J. 63 (2002) (same); Reva B. Siegel, From Colorblindness to Antibalkanization: An Emerging Ground of Decision in Race Equality Cases, 120 YALE L.J. 1278 (2011) (same); Kathryn Abrams, Elusive Coalitions: Reconsidering the Politics of Gender and Sexuality, 57 UCLA L. REV. 1135 (2010) (same). In addition, as one of us has argued elsewhere, sometimes employers pursue race or gender neutral strategies as part of an effort to discriminate against a particular group, and claim as secondary casualties some members outside of the targeted class. Universalist solutions would provide a remedy to both the intended and incidental casualties of discrimination. Camille Gear Rich, Marginal Whiteness, 98 CAL. L. REV. 1497 (2010).

${ }^{50}$ Clarke, supra note 2 at 1223.
} 
direct contrast to other work that uses the rise of post-racialism as an opportunity to recast racial equality arguments in new frameworks and idioms, and in this way convince post-racial subjects that they do have an interest in racial justice. ${ }^{51}$

Moreover, arguments that stress universalism's tactical or strategic value may strike antidiscrimination advocates as somewhat disturbing. Supporters of universalism who rely merely on tactical claims are basically conceding that discrimination is still central in understanding contemporary social conflicts, but they contend that it is better to mask this issue, rather than argue with judges and juries who have adopted post-racial understandings. Katie Eyer has been a strong defender of universalism based on its alleged strategic advantages. She acknowledges that race discrimination is still a significant problem and further that racism has taken on multiple complex forms. ${ }^{52}$ She further acknowledges that most lay persons and judges currently are ill-informed about modern racism and therefore ill-equipped to recognize contemporary discrimination patterns. Her solution, however, is to urge litigators to use universalist claims to secure "wins" for race and sex discrimination plaintiffs, because universal claims are socially more palatable. ${ }^{53}$ The mistake in such strategies is in emphasizing short term "wins" rather than taking on the more difficult project of educating and persuading persons who are unprepared to recognize contemporary racism. Supporters who stress universalism's symbolic value also are accommodating (rather than challenging) post-racial understandings. This is because the symbolic message sent by universalism is that race is no longer essential to understanding social inequality. Finally, arguments about universalism's substantive advantages also have a connection to post-racialism. To accept these arguments, at bottom, one must conclude that race is less helpful than other neutral variables in identifying social structures that lead to subordination.

By way of contrast, some of Clarke's critiques do attempt to reveal universalism's disturbing connection to post-racialism. In this way her work dovetails nicely with Sumi Cho's observation that universalism is one of the key pillars of post-racial thinking. ${ }^{54}$ Specifically, Clarke warns

\footnotetext{
51 See, e.g., Richard Ford THOMSPOn: Rights GONE WrOng: How LAw CORRUPTS THE STRUGGLE FOR EQUALITY (2011)(proposing that antidiscrimination inquiries should move away from the concept of intent because it requires inquiry into conceptually difficult psychology questions and instead towards addressing organizational structures and practices that have discriminatory effects). The virtue of Ford's approach is that he accommodates the postracial subject's anxiety about being labeled racist but still challenges what Rich calls post-racial rage - the emotional resistance and anger post-racial subjects show when seemingly neutral practices are revealed to have discriminatory effects. Instead, Ford finds a way to cast the obligation to disrupt these practices as a less blameworthy but still significant negligence problem. Rich's work attempts to engage with this issue as well, by showing post-racial subjects how whiteness injures even those subjects who claim white identities. See Rich, Marginal Whiteness (2010), supra note 49 (showing how race neutral strategies for discriminating against blacks also injure low status whites, giving whites an economic interest in disrupting minority targeted discrimination in the workplace). See also Rich, Decline to State, supra note 28 (using neo-liberal discourse of personal responsibility to raise questions about the moral integrity of persons that refuse to identify by race and participate in conversations about racial diversity).

${ }^{52}$ Eyer, supra note 34 at 1278 .

${ }^{53} I d$.

${ }^{54}$ Critical race theory scholars, in particular have raised concerns about universalism. See Cho, supra note 2 , at 1602 (discussing her critiques and arguments offered by john a. powell). Cho explains that universal programs and
} 
that the displacement of particularist (discrimination) policies by more universal ones risks neglecting the core constituents who truly need antidiscrimination laws' protection by forcing them to seek redress under general "fairness" laws. ${ }^{55}$ She also warns about universalism's symbolic message, arguing that universalist programs fail to signal the need for continued vigilance against discrimination because they replace specific antidiscrimination norms with generic norms about fair treatment. ${ }^{56}$ Bagenstos and Clarke both agree that universalist arguments can rob antidiscrimination laws of much of their moral command, as they require that race-based and gender-based rights are swallowed into broader universalist protections. ${ }^{57}$ Yet despite these concerns, both Bagenstos and Clarke end up endorsing some role for universalism. Bagenstos believes that a mix of protections is probably best suited to addressing contemporary discrimination dynamics, and warns litigators that eschewing universalist solutions may disadvantage their clients given universalist arguments' high chance of success. Clarke agrees, but points to new dangers on the horizon in a universalist world. In her view universal protections will merely become particularist again through interpretation or enforcement, as protected class groups will invoke these universalist protections more than others. ${ }^{58}$

Our work raises distinctly different concerns about the universal turn, ones generated by observing the operationalization of universalism by attorneys as they make plaintiff selection and claim selection decisions. Clarke and Bagenstos imagine a world with a mix of protections, particularist and universalist, each with its own role to play in advancing equality for protected class groups. In contrast, our research suggests that, rather than maintaining a balanced mix of claims, pragmatism is driving particularist claims to the margins of the employment litigation market. Specifically, pragmatism drives lawyers to strongly prefer universalist claims and because of opportunity-cost concerns, decline to litigate particularist claims, causing these claims to dramatically recede in importance. If the trends we describe take hold, over the long term universalism will structure the employment litigation market - and it will do so because of pragmatic attorney preferences.

\section{Understanding Post-Racial Hydraulics}

Scholars' discussion of universalism's virtues and shortcomings thus far have operated at a high level of abstraction, and as a consequence have failed to engage with some of the market effects and operational difficulties triggered by the switch from particularist to universalist

policies historically have been "anything but universal." Id. at 1602 . Instead they were constructed to address a "predictably narrow category of beneficiaries." Id. For example, programs like the G.I. Bill and Social Security, while framed as universalist, "were all premised on a model recipient who was white, able-bodied, and male." Id. Yet this history of failed or false universalism has been obscured in discussions of universalism in the post-racial era.

${ }^{55}$ Clarke, supra note 2 at 1247 ("Universal expansion of civil rights laws . . . could dilute the rights of disadvantaged groups by trivializing the more serious harms of discrimination and undermining support for antidiscrimination in general."').

${ }_{56} \mathrm{Id}$. (noting that "antidiscrimination norms might be lost if they are assimilated in to universal norms").

${ }^{57}$ Bagenstos, supra note 13 at 114 (drawing on Clarke to note that the "civil rights' label has a powerful cachet in American politics"). Bagenstos further catalogs the strategic, substantive, and expressive dangers associated with relying exclusively on universalist solutions to civil rights problems. Id. at 113-18 (discussing tactical problems); 121-24 (discussing substantive problems); 126-27 (discussing expressive problems).

${ }^{58}$ Clarke, supra note 2 at $1270-75$. 
claims. In this Section, we introduce these second order drivers, what we call post-racial hydraulics, set in motion by the universal turn. In order to give the reader insight into the pragmatic calculus attorneys make when choosing between particularist versus universal claims, we provide the reader with a brief summary highlighting the similarities and differences between the particularist race discrimination protections under Title VII and the universalist protections offered by the FLSA. We then invite the reader to re-consider a famous FLSA case, Heath $v$. Perdue Farms, as a thought experiment, considering what can happen when attorneys are incentivized to winnow away particularist proof of discrimination in the course of shaping universalist claims.

\section{i. $\quad$ Title VII vs. the FLSA: Choosing Between Workplace Fairness Claims}

At bottom, both Title VII and the FLSA are statutes aimed at guaranteeing workplace fairness; however, each statute pursues this aim differently. Title VII of the Civil Rights Act of 1964 protects employees against discrimination on the basis of race, sex, national origin, religion, and color. ${ }^{59}$ In Title VII cases that allege that the plaintiff suffered disparate treatment, the plaintiff must prove that she suffered an "adverse employment action" because of her membership in a "protected class." The Title VII plaintiff, therefore, bears the ultimate burden of proving that the defendant took adverse employment action against her because of discriminatory intent. $^{60}$ In recognition of the vast number of ways in which an employer can discriminate against and subordinate workers, the statute broadly prohibits "unlawful employment practices" instead of providing a specific list of prohibited actions. This approach gives the statute a certain flexibility and dynamism as it responds to the multiple and changing ways an employer may attempt to express bias against a worker based on race.

For example, Title VII "hostile environment" doctrine illustrates the capacious protections offered under the statute. As practitioners know, a "hostile environment," claim can be based on any number of factors: physical aggression, harassing remarks, racially offensive pictures or even nicknames. ${ }^{61}$ The emphasis in the hostile environment inquiry is on identifying the full range of atmospheric conditions and concrete actions taken to marginalize a targeted worker. As long as the plaintiff alleges sufficient facts to show that the hostile or harassing behavior was "severe or pervasive" enough to adversely affect her ability to work, she has a claim. Title VII also permits disparate impact cases, in which the plaintiff is required to show that a facially neutral employer practice produced results that were adverse to a protected class. ${ }^{62}$ Prevailing plaintiffs can secure compensatory and punitive damages as well as injunctive relief. ${ }^{63}$

\footnotetext{
${ }^{59} 42$ U.S.C. $§ 2000 \mathrm{e}-2$ (a).

${ }^{60} \mathrm{Id}$. (prohibiting an employer's decision "to fail or refuse to hire or to discharge any individual, or otherwise to discriminate against any individual with respect to his compensation, terms, conditions, or privileges of employment, because of such individual's race, color, religion, sex, or national origin") (emphasis added).

${ }^{61}$ See, generally, Zev J. Eigen, David S. Sherwyn, When Rules are Made to be Broken, 109 Nw. U. L. REV. 107 (2014) (describing the history and current status of sexual harassment law).

${ }^{62}$ Griggs v. Duke Power Co., 401 U.S. 424 (1971) (recognizing disparate impact claim).

${ }^{63}$ Key issues in Title VII race discrimination litigation include questions about whether the challenged employment practice counts as sufficiently "adverse" under the statute; whether other, nondiscriminatory reasons explain the
} 
In contrast, the Fair Labor Standards Act of 1938 does not require an inquiry into protected class status, and instead guarantees all covered workers an hourly minimum wage and premium overtime pay for every hour worked above forty in a workweek. ${ }^{64}$ Discriminatory intent is not necessary to establish an employer violation in an FLSA wage and hour case. ${ }^{65}$ Prevailing plaintiffs can recover their unpaid back wages and, in most cases, an equal amount in liquidated damages, as well as attorneys' fees and costs. ${ }^{66}$ Importantly, the FLSA covers a much narrower number of adverse employment actions than Title VII - focusing only on an employer's pay practices. $^{67}$ Consequently, any lawyer who prefers to bring a claim under the FLSA will have to set aside seemingly "smaller scale," race-based unfavorable treatment that would be actionable under Title VII, and focus instead on the wage and hour issues covered by the FLSA.

When viewed side by side, the FLSA and Title VII create clear incentives for attorneys. The ubiquity of wage and hour violations in many workplaces - documented in repeated studies and acknowledged even by defense lawyers $-{ }^{68}$ makes it relatively easy to find wage and hour issues when an client appears with a complaint about workplace discrimination. Also, as Noah Zatz has observed, "only an ostrich could fail to notice how often the lowest paid workers hail from groups central to antidiscrimination projects . ..." ${ }^{69}$ These low wages very often may be caused by FLSA violations. Moreover, wage disparities and lower pay may be some of the simplest ways for an employer to express bias against a disfavored racial group. The FLSA

unfavorable treatment; and, on occasion, whether the person who seeks to invoke race discrimination protections is entitled to claim a particular racial identity.

${ }^{64} 29$ U.S.C. $\S 203$ et seq.

${ }^{65}$ An employer's intent would be relevant in cases brought under the Equal Pay Act, which prohibits sex discrimination in pay and was codified as part of the FLSA. Intent would also be relevant to an inquiry under the FLSA's anti-retaliation provision. 29 U.S.C. $§ 215(\mathrm{a})(3)$. Finally, employer intent is relevant to the FLSA statute of limitations: a plaintiff who can prove that her employer violated the FLSA willfully can extend her statute of limitations by one year. McLaughlin v. Richland Shoe Co., 486 U.S. 128, 135 (1988) ("Ordinary violations of the FLSA are subject to the general 2-year statute of limitations. To obtain the benefit of the 3-year exception, the Secretary must prove that the employer's conduct was willful[.]").

${ }^{66} 29$ U.S.C. $\S 216$ (b) ("Any employer who violates the provisions of . . this title shall be liable to the employee or employees affected in the amount of their unpaid minimum wages, or their unpaid overtime compensation, as the case may be, and in an additional equal amount as liquidated damages. . . The court in such action shall, in addition to any judgment awarded to the plaintiff or plaintiffs, allow a reasonable attorney's fee to be paid by the defendant, and costs of the action.").

${ }^{67}$ We need a footnote here to acknowledge that the FLSA contains an anti-retaliation provision that does cover all manner of employer reprisals, and also that the Equal Pay Act is part of the FLSA

${ }^{68}$ For statistics on the prevalence of wage and hour violations, see Annette Bernhardt et al., Broken Laws, Unprotected Workers: Violations of Employment and Labor Laws in America's Cities (2009), available at http://www.nelp.org/page/-/brokenlaws/BrokenLawsReport2009.pdf?nocdn=1 at 2 (describing findings based on surveys of approximately 4,300 low-wage workers in New York, Chicago, and Los Angeles of widespread FLSA violations); Siobhan McGrath, A Survey of Literature Estimating the Prevalence of Employment and Labor Law Violations in the U.S., Brennan Ctr. for Just. (Apr. 15, 2005), http://brennan.3cdn.net/bdeabea099b7581a26_srm6br9zf.pdf; see also Interview by Charlotte S. Alexander (Aug. 5, 2014); notes on file with authors ("Unfortunately for employers, there is almost always something that can be found wrong with a pay practice ....”).

${ }^{69}$ Noah D. Zatz, The Minimum Wage as a Civil Rights Protection: An Alternative to Anti-Poverty Arguments?, 2009 U. CHI. LEGAL F. 1, 6 (2009) (theorizing about the commonalities between anti-discrimination and minimum wage law). 
makes it easy to address this wrongful conduct, as it is agnostic about whether the employer is motivated by a conscious or unconscious desire to discriminate against the employee. Indeed, the FLSA does not require a showing that discriminatory or malicious intent motivated an employer's unlawful pay practices. Rather, once the plaintiff establishes that her wages fell below the statutory minimum or violated overtime requirements, the employer is liable and required to make the employee whole.

The issues described above become clearer and more concrete as we examine our next case, Heath v. Perdue Farms, which is taught to students in employment law classes as a wage and hour case. ${ }^{70}$ Heath functions well as a thought experiment, allowing us to consider what falls by the wayside when particularist Title VII race discrimination claims are recast under the FLSA's universalist provisions. ${ }^{71}$

\section{ii. Case Study: Heath v. Perdue Farms}

In Heath, a group of 100 chicken catchers sued their employer, Perdue Farms, for unpaid overtime under the FLSA. Chicken catching is, in the words of the Heath court, "physically arduous, dangerous and unpleasant.", "Catchers go from farm to farm rounding up fully grown chickens in the middle of the night, stuffing them into cages, and loading them onto trucks for delivery to processing plants... Workers wear little protective clothing as they stoop down to pick up six or seven panicked birds by their powerful [talons]."73 The Heath plaintiffs alleged that, although they worked for more than forty hours per week, they were paid only a flat fee per number of chickens caught, regardless of the number of hours they worked, and without the overtime premium required by the FLSA. $^{74}$

Perdue defended by arguing that the chicken catchers were employed solely by middle-man crew leaders who contracted with Perdue, and not by Perdue itself. The court rejected Perdue's argument in its entirety, granted summary judgment to the plaintiffs on liability, and extended the plaintiffs' statute of limitations by an extra year because Perdue's violation of the FLSA was "willful." Specifically, the Internal Revenue Service had previously warned Perdue that its employment practices were in violation of the FLSA, but the company had ignored this

\footnotetext{
${ }^{70}$ Heath, et al v. Perdue Farms, Inc., Docket No. 1:98-cv-03159 (D. Md. Sept 18, 1998); See, e.g., MARION G. Crain, Pauline T. Kim \& Michael L. Selmi, Work LAW: CASES AND MATERIALs 782 (2d ed. 2010) at 782 (excerpting Heath v. Perdue Farms, Inc., 87 F. Supp. 2d 452 (D. Md. 2000)).

${ }^{71}$ To be clear, we have no evidence that the plaintiffs' attorneys in Heath were motivated by the dynamics we describe here; however, we posit that this is exactly the kind of case that is likely to be fast tracked into a FLSA framework in the post-racial era.

${ }^{72}$ Heath, 87 F. Supp. 2d at 455.

73 SteVe Striffler, Chicken: The Dangerous Transformation OF AMERICA's FAVORITE FoOD 162 (2005); see also Charlotte S. Alexander, Explaining Peripheral Labor: A Poultry Industry Case Study, 33 BERKELEY J. EMP. \& LAB. L. 353 (2012) (describing chicken catching).

${ }^{74}$ Heath, 87 F. Supp. 2d at 455.
} 
warning. ${ }^{75}$ Ultimately, the 100 Heath plaintiffs received approximately $\$ 2$ million from Perdue in back overtime pay in settlement of their claims. ${ }^{76}$

Heath features many of the virtues of universalism identified by scholars. For example, universalism's supporters might say that the FLSA claims were symbolically helpful, as the remedy they offered - unpaid overtime - was available to all workers regardless of race. Indeed, there is no mention of the Heath plaintiffs' race in the record; the court was able to adjudicate their FLSA claims without reference to their membership in any identity group. Second, the FLSA victory was arguably substantively more helpful to a larger group of workers than just to those in a particular class protected by Title VII. By challenging their employer's attempt to deny an employment relationship, the Heath chicken catchers created precedent that would serve all workers subject to similarly structured work arrangements. Indeed, workers in occupations as diverse as painting, construction, and janitorial services have all drawn on Heath to successfully claim employee status under the FLSA. ${ }^{77}$ Third, as a strategic matter, the FLSA claims in Heath were likely easier or more "winnable" than theoretical Title VII race discrimination claims would have been. The inquiry in Heath focused on objective FLSA questions concerning the business relationships among Perdue, the crew leaders, and the plaintiffs and, ultimately, the number of hours the plaintiffs worked and the amount of their pay. ${ }^{78}$ Also, the company was found to have willfully violated the statute because another government entity, the IRS, warned Perdue that its compensation arrangement for chicken catchers was illegal, but Perdue continued to rely on this arrangement nevertheless. In this way, the attorneys litigating the FLSA case had a much simpler task than if they had proceeded under Title VII, as they were able to avoid the messy bias inquiries that are necessary to prove race discrimination. ${ }^{79}$ Fourth, the universalist FLSA claim allowed the Heath plaintiffs to seek redress without first being subject to an essentializing inquiry about their race - an inquiry that is sometimes a threshold question in Title VII cases. ${ }^{80}$

\footnotetext{
${ }^{75}$ Id. at 457 ("Applying [the FLSA joint employment] factors to the undisputed facts presented makes it abundantly clear that Perdue is the employer of both the crew leaders and the chicken catchers."); id. at 459 (finding "no doubt that [the relationship between Perdue and the plaintiffs] is an employer/employee relationship for the purpose of the FLSA").

${ }^{76}$ Gail Gibson, Perdue Agrees to Give $\$ 1.7$ million to 100 Workers to Settle Lawsuit, The Baltimore Sun (May 10 , 2001).

${ }^{77}$ Montoya v. S.C.C.P. Painting Contractors, Inc., 589 F. Supp. 2d 569, 580 (D. Md. 2008) (describing the plaintiffs as painters "of Hispanic origin and native Spanish speakers" as "akin to the chicken catchers in Heath"); Calle v. Chul Sun Kang Or, No. CIV.A. DKC 11-0716, 2012 WL 163235, at*7 (D. Md. Jan. 18, 2012) (following Heath in FLSA case involving construction worker); Quinteros v. Sparkle Cleaning, Inc., 532 F. Supp. 2d 762, 774 (D. Md. 2008) (same in case involving janitors).

${ }^{78}$ Heath, 87 F. Supp. 2d 452;

${ }^{79}$ The plaintiffs' attorneys in Heath were also able to take advantage of the FLSA's particularly broad definition of "employee" to attach liability to Perdue. See United States v. Rosenwasser, 323 U.S. 360, 363 n.3 (1945) (quoting then-Senator Hugo Black as describing the FLSA's use of "employee" as having "the broadest definition that has ever been included in any one act.").

${ }^{80}$ Indeed, questions about how we define who is protected under Title VII against race discrimination have grown in importance in recent years. Scholars have noted that discrimination seldom takes the form of old style explicit discrimination in today's world and instead Title VII must address new forms of discrimination that stem from cognitive bias, like implicit discrimination, but are not adequately addressed by discrimination models that focus on clear intent evidence. See, e.g., Samuel R. Bagenstos, The Structural Turn and the Limits of Antidiscrimination
} 
However, Heath starts to look different when we learn that all of the 100 chicken catcher plaintiffs were African-American, when we discover that only African Americans held this brutal, low-paid job where "[d]ust, feathers and ammonia choke[d] the air [inside the chicken houses]. . . and fans turn it into airborne sandpaper, rubbing skin raw." 81 Though the court documents are silent about race, secondary sources tell us that on the Delmarva Peninsula where the events of Heath took place, "African American involvement in commercial poultry production occurred in an environment of intense racial segregation[.]" 82 It was a historical fact that chicken catchers were African-American, while other poultry industry occupations were filled by Latinos or whites. ${ }^{83}$

Heath is therefore a shadow case of race discrimination, where clear evidence of occupational segregation never saw the light of day. In an alternative version of the case, the plaintiffs could have challenged Perdue's and the crew leaders' recruitment and hiring practices, job arrangements, and promotion schemes that tracked minorities into disfavored, lower-paid job categories. Admittedly the task of proving discriminatory intent on Perdue's part would have been difficult, rendered even harder by the multi-layered employment relationship between chicken catchers, crew leaders, and Perdue. Indeed, while there is no established precedent that bars evidence related to the new subtler forms of contemporary bias, there is no existing doctrinal vehicle that facilitates much less requires consideration of such evidence. However, plaintiffs do make, and win, such arguments under Title VII. ${ }^{84}$ And historically we have relied on lawyers to take on this struggle, to ensure that the law reflects (and in some ways advances) contemporary social understandings.

However, when faced with a case like Heath in the post-racial era, the pragmatic lawyer would likely work the case up in its two alternative forms, and then logically decide to winnow away the evidence of race discrimination from the easier, simpler FLSA suit. Pragmatics trump

Law, 94 CALIF. L. REV. 1, 5 (2006); Linda Hamilton Krieger, The Content of Our Categories: A Cognitive Bias Approach to Discrimination and Equal Employment Opportunity, 47 STAN. L. REV. 1161 (1995); Sturm, supra note 4 at 458 (2001). Cf. Stephen M. Rich, The One Law of Race, 100 IowA L. REV. 201, 258 (recognizing seeming desire for descriptive convergence in discussing how discrimination operates in various areas of civil rights law but arguing that different social contexts may produce different ways of discriminating and different statutory and doctrinal rules and standards to address distinct iterations of the same social problem).

${ }^{81}$ Peter S. Goodman, Eating Chicken Dust: In an Automated Industry, Catchers Still Must Grab Birds by Hand, Washington Post, page A23 (Nov. 28, 1999).

${ }^{82}$ SOlOMON IYOBOSA OMO-OSAGIE II, COMMERCIAl POUltRy Production ON MARYLAND'S LOWER EASTERN SHORE: THE ROLE OF AFriCAN AMERICANS, 1930S to 1990S at 133 (2012).

${ }^{83}$ OMO-OSAGIE, supra note 82 at 133 (describing chicken catchers on the Lower Maryland Eastern Shore as "mainly African Americans"); Goodman, supra note 76 ("For years, catching has been dominated by African Americans."); Steven Greenhouse, Priest vs. 'Big Chicken' In Fight for Labor Rights, New York Times (Oct. 6, 1999) (describing "African-American chicken catchers, Hispanic slaughterhouse workers and white chicken farmers"); KIM BOBO, WAGE THEFT IN AMERICA 47 (2009) ("In the Delaware peninsula, which is known for its chicken processing, Central American immigrants dominate the chicken processing lines and African American workers are the chicken catchers.").

${ }^{84}$ As a counter example, see Colindres v. QuietFlex Manufacturing Co., Second Amended Complaint, Docket No. 01-cv-04319, 2002 WL 34346793 (S.D.Tex. Nov. 1, 2002) (alleging violations of both the FLSA and Title VII arising out of employer's segregation of Latino workers into a single department and unlawful pay practices). 
idealism; the universalist claim is mapped over the particularist one. This observation gave the authors pause when we considered what happens when large groups of lawyers make this same calculation. In broader terms, what happens when universalism takes hold in civil rights communities, incentivizing employment attorneys to abandon Title VII litigation and pursue remedies under universalist statutes? First, we hypothesized that the market would reshape itself in a manner that would cause plaintiffs to have difficulty finding employment lawyers to take their cases. For example, the chicken catcher plaintiffs in Heath may have viewed their wages and working conditions as causally connected with their race. They may have searched unsuccessfully for a lawyer who would bring a claim under the rubric of civil rights, and ultimately abandoned their employment discrimination claims in favor of overtime claims under the FLSA. Second, we concluded that the legal standards needed to advance our understanding of discrimination would fail to emerge because the universal turn would decrease the number of race discrimination cases that were filed involving close and murky discrimination questions. In other words, the precedents necessary to establish occupational segregation like that in Heath cannot be generated when the case is presented as a FLSA action. And the lack of litigation creates a third concern: that as a general social matter people are encouraged to believe race discrimination is rare and employment discrimination litigation is largely unnecessary.

Fourth, we worried about client voice and agency. We wondered whether the plaintiffs in Heath felt satisfied with the resolution of their claims if they believed that discrimination was an important part of the story that they wanted to tell. Certainly there may have been additional facts that explained why some of the hardest and dirtiest work in poultry processing was allotted to a job category populated by African Americans. Additionally there may have been other forms of subordination at work, such as racial harassment that would have been part of a larger discrimination story, but could not have been accommodated under the FLSA. In these circumstances, plaintiffs might feel robbed of an opportunity to fully address discrimination in the workplace in a comprehensive fashion. Additionally, plaintiffs asked to reframe their particularist grievances into universalist claims are being told (or disciplined) in a not-so-subtle fashion that society is no longer interested or invested in combatting problems associated with race discrimination.

To organize and test these observations about the ways in which universalism shapes the employment litigation market and manifests in lawyer-client interactions, we initiated a series of conversations with a purposeful sample of fifteen senior, experienced employment litigators.

\section{EVIDENCE AND TheORETICAl CONTEXT For Post-Racial Hydraulics}

\section{A. Post-Racial Hydraulics - Origins and Methodology}

Our theory of post-racial hydraulics was produced by a unique cross-pollination opportunity between two empirical scholars working on FLSA and Title VII claims and another scholar who uses Title VII litigation to chart sociological changes in contemporary racial ideology. 
Alexander's ongoing work on the empirics of the recent FLSA litigation boom ${ }^{85}$ led her to observe that the number of Title VII cases on federal courts' dockets has fallen since the late 1990 s, while the number of FLSA cases has risen dramatically, at roughly the same time. ${ }^{86}$ Eigen's work as an expert in wage and hour class actions for the past eight years has allowed him to observe and assess the litigation strategies of plaintiff-side and defense-side attorneys as they shift between Title VII and FLSA claims, noting a clear preference for FLSA claims based on pragmatic assessments about the relative success of each class of claims. Rich provided a sociological context for understanding some of the ideological repercussions of the shift to universalism and its relationship to post-racialism. In this way the authors were able to create a framework for charting the effects of universalist strategies, both at the macro-level, in terms of institutional understandings, as well as at the micro-level, in terms of individual interactions and understandings.

The authors' discussions allowed us to identify four primary drivers in the employment litigation market that have resulted from universalism. We call these drivers post-racial hydraulics because they are a direct result of the turn toward universalism and yet, while wholly predictable, have not been noticed or discussed thus far in the literature on universalism. We then developed a "purposeful" or "judgment" sample of fifteen senior, experienced employment lawyers who had worked on both Title VII race discrimination claims and FLSA wage and hour claims. ${ }^{87} \mathrm{We}$ selected this group because we concluded that they would be the most knowledgeable about attorneys' universalist strategies and could comment on the hydraulic relationship, if any, between Title VII and FLSA claims. ${ }^{88}$

The authors recognize that law reviews have not published many studies using purposeful samples or even qualitative data more generally, and therefore our research methods may appear somewhat unfamiliar. Therefore some background and clarification is necessary to understand how this project achieves its goals. In a qualitative study using a purposeful sample, researchers do not set out to construct a random sample. Instead, they actively select a group of research subjects who are, given the research project's aims, the most productive sample to address the research question posed. ${ }^{89}$ Purposeful samples are often developed by targeting the variables of

\footnotetext{
${ }^{85}$ Charlotte S. Alexander, An Empirical Portrait of Federal Wage and Hour Litigation, supra note 14.

${ }^{86}$ For a discussion of the data we relied on develop an understanding of FLSA and Title VII filing trends nationally, see Appendices A and B.

${ }^{87}$ A number of seminal works on lawyers' experiences have relied primarily on qualitative research. AUSTIN SARAT AND William Felstiner, Divorce LAWYERS AND THEIR CliENTS: POWER AND MEANING IN THE LEGAL PROCESS, (1995) (discussing results of qualitative study of divorce lawyers); M. Thornton DISSONANCE AND DISTRUST WOMEN AND THE LEGAL PROFESSION (1996) (discussing results of qualitative study of female attorneys). See also OXFORd HANDBOOK OF EMPIRICAL LEGAL RESEARCH (EDS. PETER CANE \& HERBERT KRITZER OUP 2010) (discussing importance of qualitative research more generally).

${ }^{88}$ A snowball sampling technique refers to a process in which a researcher begins with a group of research participants known to her (or otherwise identified in advance in some way), and then asks each participant to provide details of someone else whom they consider to be a good research subject for the purposes of the study. In this way, the researcher gradually builds up a larger sample of participants. M.N. Marshall, Sampling for Qualitative Research, 13 FAMILY PRACTICE 523-525 (1996).

89 "Qualitative researchers recognize that some informants are 'richer' than others and that these people are more likely to provide insight and understanding for the researcher. Choosing someone at random to answer a qualitative
} 
interest to the researchers, and are based on the researchers' practical knowledge of the research area, as well as the available literature and evidence from the initial phase of the project itself.

In our case, initial evidence showed rising levels of FLSA litigation and shrinking numbers of Title VII claims. Consequently, two of the authors mined their contacts within the employment bar to identify attorneys with established employment litigation practices in jurisdictions in which FLSA filings seemed to be rising and Title VII filings seemed to be falling. ${ }^{90}$ We determined that we hit a saturation point — the point at which a sample has produced enough data to map the specific contours of a potential theory ${ }^{91}$ - after our initial round of fifteen attorney interviews. ${ }^{92} \mathrm{We}$ are planning a broader quantitative and qualitative project involving further case filing data analysis and additional attorney surveys now that the initial phase of our research has allowed us to map the hydraulic trends that we intend to study. ${ }^{93}$ We have chosen to present the early results from our qualitative sample here because we have discovered issues of concern that are absent from the existing theory- and policy- focused literature on universalism.

As the discussion below shows, our interviews were relatively narrow and targeted on the dynamics of employment law practice. While our sample size is small, our goal is modest: to map the hydraulics described above. Because our interview subjects universally provided support for our conception of "post-racial hydraulics," we proceeded to formalize our theory and prepare for the next level of broader qualitative and quantitative study. ${ }^{94}$

\section{B. Attorney Interviews}

Our interviews revealed the subject attorneys' assessments of the relative viability of Title VII and FLSA claims and confirmed that attorneys are engaging in a process of shifting claims away from the particularist provisions of Title VII and toward the universalist provisions of the FLSA. The interviews also illuminated specific mechanisms by which the post-racial hydraulic process occurs, showing that lawyers are declining representation to clients with Title VII claims and instead representing different clients with FLSA claims. In addition (or in the

question would be analogous to randomly asking a passer-by how to repair a broken down car, rather than asking a garage mechanic - the former might have a good stab, but asking the latter is likely to be more productive." See

Leslie C. Levin. Guardians at the Gate: The Backgrounds, Career Paths, and Professional Development of Private US Immigration Lawyers, 34 LAW \& SOCIAL INQUIRY 399-436 (2009).

${ }^{90}$ Because our sample size was small, we have chosen to keep the identities of the research subjects private as a condition of their participation.

91 See CANE \& KRITZER.

${ }^{92}$ Not all interviews are excerpted in this Article.

${ }^{93}$ The next phase of our research will be based on an "iterative process of qualitative study design" This process involves building one's general theory based on the emerging data form the initial group of research subject interviews and then selecting a new sample to examine and elaborate on this theory. Marshall, supra note 88 at 523 525.

${ }^{94}$ As Levin explains, sample size is highly dependent on the kind of study being produced. "For simple questions or very detailed studies, this might be in single figures; for complex questions large samples and a variety of sampling techniques might be necessary. In practice, the number of required subjects usually becomes obvious as the study progresses, as new categories, themes or explanations stop emerging from the data (data saturation)." Levin, supra note at 89 at $399-436$. 
alternative), an attorney may agree to represent a client who arrives at his office describing a race discrimination claim, but encourage the prospective client to recharacterize his claim as a raceneutral or universal wage and hour violation.

As an initial matter, the attorneys in our sample were united in their judgment that winning a Title VII claim in federal court today is much harder than in the past, and in their perception that FLSA claims can be substantially easier to litigate, and thus more viable, than Title VII claims. One plaintiffs' attorney with twenty years' experience with all types of employment claims commented on courts' hostility to Title VII cases, expressing the view that "[d]iscrimination cases are basically unwinnable in most federal circuits." "95 Another senior attorney who co-chairs the labor and employment department at her defense firm noted the problems for the plaintiffs' bar in litigating discrimination claims: "At the end of the day, recovering back pay for a worker was not all that much, attorney fees were not always assured, and emotional distress and punitive damage awards definitely were not a sure thing or even all that high at the end of trial." 96

Similarly, the attorneys all concurred in the view that, in the words of one attorney, "FLSA cases are easier." 97 He explained that there are many procedural and substantive advantages to litigating FLSA claims, including avoiding the prohibitive cost of the motions practice required to achieve Title VII class certification; the steep legal standard for Title VII class certification since Wal-Mart v. Dukes, ${ }^{98}$ which made class actions significantly harder for plaintiffs to prove in instances where employers delegate extensive authority to managers and exercise less centralized control over employment decision making; the "low hanging fruit" character of FLSA cases, given the ubiquity of employers' wage and hour violations; and the ability to litigate a wage and hour case without having to prove intent. ${ }^{99}$ Two other plaintiffs' attorneys echoed these latter remarks about the difficulties of proving intent in Title VII cases. A plaintiffs' attorney with twenty-two years" experience described such proof as "elusive," in contrast with the "objective evidence, such as written employment policies and time and payroll records" that can be used to support FLSA and state wage and hour claims. ${ }^{100}$ Another plaintiffs' attorney with ten years' experience summarized the advantages of the FLSA's proof requirements:

Wage and hour claims are much more objectively provable; rarely do the supervisors' intent or other subjective factors come into play. Unpaid overtime is unpaid overtime; missed meal periods are missed meal periods, allowing me to prove my case with the defendant's records instead of trying to muster a whole lot of evidence about someone's intent that they will never admit to. In that way,

\footnotetext{
${ }^{95}$ Interview (Aug. 5, 2014), supra note 68.

${ }^{96}$ Interview by Zev Eigen (Aug. 14, 2014); notes on file with authors.

${ }^{97}$ Interview (Aug. 5, 2014), supra note 95.

${ }^{98}$ Wal-Mart Stores, Inc. v. Dukes, 131 S. Ct. 2541 (2011).

${ }^{99}$ Interview (Aug. 5, 2014), supra note 95.

${ }^{100}$ Interview by Zev Eigen (Aug. 15, 2014); notes on file with authors.
} 
wage and hour claims feel more straight-forward. ${ }^{101}$

And in the words of a defense attorney:

In the early days of the 21 st century, the plaintiffs' bar realized that the oftconsidered ugly step-child of the employment bar, the FLSA and comparable state wage and hours laws, was actually a lot prettier than it looked. It offered automatic attorneys' fees, mandatory liquidated damages, and the legal standard was simply - either you paid properly or you didn't; there was no wiggle $\operatorname{room}[.]^{102}$

These interviews also help to illuminate the inner workings of post-racial hydraulics - the actual mechanisms by which plaintiffs' lawyers shift claims from Title VII to its now-prettier relative, the FLSA. Our interviews, along with other lawyers' remarks in the media, suggest the existence of two, non-exclusive methods of claim-shifting. First, lawyers may simply be accepting more FLSA cases and declining representation in employment discrimination cases. Second, attorneys may be "finding" wage and hour violations within workers' complaints of discrimination and recharacterizing what previously would have been brought as a race discrimination case as a wage and hour case. The net result of these two methods is the same: a hydraulic flow away from the particularist Title VII and toward the universalist FLSA.

With respect to declining representation, one plaintiffs' attorney noted that "[o]ver the last ten to fifteen years, plaintiff-side lawyers sought to allocate the risks of contingent practice by shifting from more difficult to prove cases based on more expensive to gather subjective testimony [Title VII], to cases largely proven with an employer's own records [the FLSA]." 103 Noting the relative ease and speed of proving FLSA allegations, he concluded, "All these factors have combined to drive this shift in plaintiff-side employment practice."104 In a published interview, plaintiffs' side employment lawyer David Borgen of the Oakland, California firm Goldstein, Borgen, Dardarian and Ho described a similar shift in his own employment practice: "When I first came to the firm [in 1990], all of my time was spent on Title VII class actions. We started our wage/hour practice in 1997, and within a year, it swallowed up 100 percent of my professional work time." 105 Strikingly, he went on to describe this caseload shift in language that

\footnotetext{
${ }^{101}$ Interview by Zev Eigen (Aug. 15, 2014).

${ }^{102}$ Interview (Aug. 14, 2014), supra note 96; see also BNA FLSA Litigator Q\&A, Christopher Deering Considers Implications of Supreme Court and NLRB Rulings, DOL Enforcement Agenda (Jan. 7, 2013) (quoting Ogletree Deakins management attorney Christopher Deering on plaintiffs' burden in FLSA versus Title VII claims: “To move forward in a wrongful discharge or employment discrimination case, it is the plaintiff-employee who is charged with the initial burden of marshaling adequate evidence that the employer possessed an illegal, discriminatory motivation for the adverse employment action. So, one may reasonably conclude that from an evidentiary burden standpoint, it is easier for a plaintiff to prevail in a FLSA case than a garden-variety discrimination case.”).

${ }^{103}$ Interview (Aug. 15, 2014), supra note 100.

${ }^{104} \mathrm{Id}$.

${ }^{105}$ BNA FLSA Litigator Q\&A, David Borgen Discusses Supreme Court's Christopher v. GlaxoSmithKline Ruling, Implications for FLSA Litigation (Oct. 1, 2012) (noting also that the shift to FLSA litigation "provided an opportunity to diversify our firm's practice which had, until then, been almost exclusively limited to Title VII class
} 
seems confirm the post-racial hydraulic hypothesis of this Article - the replacement of particularist legal protections with universalist ones: "Wage and hour litigation allows us to recover wages that should have been paid to workers under the minimum wage and overtime statutes that were enacted many years ago for the protection of all workers (not just unionized workers or women and minorities). The issues usually involve claims for basic fairness in the workplace and in the labor market.",106

The second hydraulic mechanism is the recharacterization of potential plaintiffs' claims of employment discrimination as claims of wage and hour violations. As one of the media accounts quoted above describes it, "a worker visits a plaintiffs' lawyer to complain about some form of discrimination and ends up talking generally about his or her work duties and whether he or she took breaks. The lawyer begins to get a sense of 'how compliant or noncompliant that employer is, and pretty soon you have a [FLSA] collective action going." "107 One of our interview subjects concurs, describing situations where "a terminated employee will show up at [a plaintiff's attorney's] doorstep complaining about being wrongfully terminated. The attorney or paralegal will go through the normal intake process and try and ferret out the reasons for the termination ... While the attorneys will more often than not explain that there really is not a strong case for discrimination, they will typically ask to see a copy of a pay stub" and will then discover a FLSA violation. ${ }^{108}$ Another plaintiffs' lawyer describes a similar dynamic: "If a potential claimant walked through most plaintiff-side lawyers' door today, and presented a claim that seemed most closely aligned with a race or gender discrimination claim, it is likely that the lawyer will test to see whether there are viable wage and hour claims that the lawyer would prefer to bring instead." 109

Perhaps one of the most striking examples of the second hydraulic mechanism we theorize is found in one defense attorney's description of his experiences defending wage and hour claims. This attorney reported that he has deposed numerous named plaintiffs in wage and hour class actions, and at these depositions, he routinely questions them about their initial claims, i.e. why they initially sought out a lawyer. This attorney reports that the plaintiffs "almost never

action litigation"); see also Deering, supra note 102 (commenting from a defense perspective, "The very early 2000s was when I really began handling FLSA cases in earnest... FLSA litigation, including class and collective actions, easily consumes better than half my practice time now."). Similarly, a plaintiffs' employment lawyer was quoted in 2002 that "employment discrimination attorneys 'have morphed' into wage and hour attorneys in the past few years. ... [and] plaintiffs' firms looking to bring class actions have redirected their attention to the wage and hour arena . . . ." Victoria Roberts, Attorneys Explore Reasons for Surge In Wage and Hour Lawsuits, Offer Strategies, Analysis \& Perspective, BNA DAILY LABOR REPORT at C-1 (Dec. 12, 2002); see also Rhonda Smith, Aggressive Plaintiffs' Bar, Labor Secretary Spotlighting FLSA Compliance, Speaker Says Bloomberg BNA Workplace Law Report (July 10, 2009) (quoting management attorney Nancy Patterson, describing plaintiffs' employment attorneys who "[o]ften. . . don't bring discrimination or state law claims but only file FLSA claims because they find them to be more lucrative"); Jonathan A. Segal, The New Workplace Revolution: Wage and Hour Lawsuits, FORTUNE (May 29, 2012), available at http://fortune.com/2012/05/29/the-new-workplace-revolution-wage-and-hour-lawsuits/ (“"'In the employment arena, the civil rights revolution has morphed into a kind of wage and hour revolution.'”').

${ }^{106}$ Borgen, supra note 105 (emphasis added).

${ }^{107}$ Gale Group, As Wage \& Hour Lawsuits Explode, Carriers Weigh in Against Insurability, NATIONAL UNDERWRITER PROPERTY \& CASUALTY (June 9, 2008).

${ }^{108}$ Interview (Aug. 14, 2014), supra note 96.

${ }^{109}$ Interview by Zev Eigen (Sept. 9, 2014). 
[sought help initially for] the wage and hour claims, but something more like discrimination." 110 As an example, at a recent deposition in a wage and hour case, the plaintiff said that she thought that what was being claimed was disability discrimination. He (defense counsel) informed her that the complaint as filed contained no such allegations. She appeared quite surprised to learn this. ${ }^{111}$ That is, the first time the named plaintiff discovered that she was not suing for disability discrimination, but rather for wage and hour violations (in this case pay stub reporting) was at her deposition.

Thus, taken together, our interviews provide compelling initial evidence from attorneys themselves that pragmatic concerns are causing lawyers to turn away from the particularist protections of Title VII and toward the universalist protections of the FLSA. While these qualitative data cannot capture the breadth of this phenomenon or measure its strength in shaping the market for employment discrimination claims, the sample provides us with our first "window" that will allow us to theoretically unpack the phenomenon, document its occurrence, and better understand post-racial hydraulics.

C. Post-Racial Hydraulics as Dynamics in Racial Formation

The qualitative data we collected not only confirmed our initial hypotheses about post-racial hydraulics and the connections between post-racialism and universalism, but also caused us to develop an additional, more nuanced understanding of the ways in which ideological understandings about race take hold. In our view the study of post-racial hydraulics also points to a new layer of inquiry in understanding racial formation, the sociological framework that allows scholars to chart the ways in which social understandings about race are absorbed, reflected and transformed by institutional structures. More specifically, racial formation theory invites scholars to examine the transitions and tensions between different competing racial ideologies or, in lay terms, competing racial understandings. ${ }^{112}$ Our account of post-racial hydraulics is important to the literature on racial formation because the forces we describe as post-racial hydraulics operate as macro-level factors and micro-level factors in the racial formation process. Our hope is that by revealing the larger ideological significance of these factors in the racial formation process, litigators may realize that universalism cannot be treated as merely a short term, pragmatic approach that is designed to capitalize on contemporary ideological conditions. Rather, as this discussion shows, because of the post-racial hydraulics it sets in motion, the universal turn effectively solidifies post-racial understandings and drafts as its foot soldiers in this process lawyers who may not overtly endorse post-racialism.

Michael Omi and Howard Winant explain that contemporary discussions about race should be focused on the dynamics of "racial formation" - the social, economic, and political forces that determine the ideological content understandings we hold about race and discrimination, as

\footnotetext{
${ }^{110} \mathrm{Id}$

${ }^{111} \mathrm{Id}$

${ }^{112}$ See generally Devon W. Carbado, Afterword, Critical What What?, 43 ConN. L. REV. 1593 (2011); Ian F. Haney Lopez, Post-Racial Racism: Racial Stratification and Mass Incarceration in the Age of Obama, 98 CALIF. L. REV. 1023 (2010).
} 
well as the forces that drive these understandings. ${ }^{113}$ Omi and Winant describe our substantive understandings about race and race discrimination as continuously evolving and being reworked in a process called "racial signification." 114 The understandings associated with each given ideology about race are circulated and reworked by state agencies and other institutions in a continuous process. Omi and Winant show how different ideologies compete against one another over time, as each ideological framework attempts to instantiate itself as the dominant approach for understanding race in a given period. They explain that there is no end goal in this competition between ideologies or racial projects, as multiple ideologies are constantly in play, even if one framework may gain prominence during a particular period.

Sumi Cho's work on post-racialism nicely illustrates the value in studying racial formation. She adroitly maps and explains Americans' shift from colorblindness discourse to the language of post-racialism in recent years, a transition sociologists would quickly recognize as a paradigmatic example of a shift between racial ideologies or "racial projects." 115 Omi and Winant counsel that we can learn a great deal by examining the ways in which certain ideological frameworks are undercut, resisted, or repurposed as society transitions between different historical periods. Cho gives us an opportunity to develop a richer understanding of contemporary post-racialism by charting the relationship between this contemporary framework and 1990s colorblindness discourse. Her work in describing this transition is comprehensive. She identifies institutions and mechanisms that are key in establishing post-racial understandings, as well as describing the ways in which individuals embrace and resist postracial logic.

Indeed, racial formation can be studied in two ways, either by focusing on macrodynamics or microdynamics. However, because both approaches provide key insights in understanding a particular ideological formation's social effects, the best work pays attention to both considerations. Studies that focus on the macrodynamics of racial formation focus on the way that institutions - for example, the church or the state, produce and circulate racial definitions of race, race discrimination and other social understandings. The macrodynamics approach is similar to Robert Post's "sociological" approach to the study of law. Post charges legal scholars to uncover the ways that institutions are involved in the sociological process of defining race for social actors, even as these institutions claim to simply be responding to the understandings of those they serve. ${ }^{116}$ While macro-level or top down approaches to the study of racial formation are helpful, they are incomplete without some accounting of how individuals use and rework institutional definitions, and force institutions to respond to these changed understandings. Investigations that explore these questions focus on micro-level "racial formation" processes. These studies often employ sociology and psychology to describe the ways in which individuals

\footnotetext{
113 OMI \& WINANT, supra note 15.

${ }^{114} \mathrm{Id}$.

${ }^{115}$ Cho, supra note 2 at 1589.

${ }^{116}$ Robert Post, Prejudicial Appearances: The Logic of American Antidiscrimination Law, 88 CALIF. L. REV. 1,31 (2000) (explaining that the sociological approach recognizes that law is a social practice structuring our understanding of race that attempts to shape other social practices about race).
} 
redeploy institutional definitions of race and discrimination to serve their own identity maintenance purposes.

Specifically, thus far, macro-level discussions of racial formation tend to focus on the substantive messages communicated by social institutions about race, in the form of formal definitions of race and or race discrimination. Our research allows scholars to consider the ways in which seemingly apolitical structural changes in the employment litigation market also sharply affect which messages about race are elaborated on and circulated. More specifically we argue that, because of the "voluntary," pragmatic, choices litigators make to focus on universalist claims, the employment litigation market will be structured in a way that minimizes future opportunities to initiate legal cases that would challenge post-racial understandings or to update our understanding of discrimination. This observation is important because it shows how markets themselves, over time, for non-ideological reasons, come to be structured in ways that minimize opportunities for certain kinds of racial discourse. This observation also helps us understand the ways in which certain ideological understandings become solidified through "voluntary" action of market players, even when the players may not themselves endorse or share the ideological vision promoted by their actions. Scholarly discussions of racial formation thus far have not featured any examination of actors that comply with certain ideological understandings of race (or strategically harness certain ideological understandings of race for efficiency reasons). Additionally, discussions have not considered how these actors' efficiency calculations can fundamentally structure the market (and other institutions) in sticky ways that have long term effects. One might have less concern about sticky second order ideological effects that stem from lawyers' pragmatism-motivated decisions in some contexts. However, here pragmatism drivers threaten to play a critical role because post-racialism is arguably a "racial project" in ascendance. Once a set of racial understandings has sufficient impact to shape institutional structure or shape economic markets in particular ways, it has much greater effect.

Our study of post-racial hydraulics also provides novel insight into micro-level factors as well. Specifically, our research suggests that attorneys, for non-ideological reasons, are tracking their discrimination clients into universalist litigation claims. Lawyers have special fiduciary obligations in part because they play such a powerful role in helping individuals understand and represent their injuries. Certainly, some lawyers believe that translating claims into a universal form is the best way to discharge their fiduciary obligations because they are assisting their clients in structuring claims that are most likely to succeed at trial. However, even with the most frank and supportive discussion, many clients will be intimidated. Other clients are very strongly inclined to simply trust the expertise of their attorneys. Finally, some may not realize the stakes of what it is that they are deciding when they "agree" to adopt a universalist framework. Our concern is that little attention has been paid to the ways in which attorneys may discipline discrimination targets to see their claims in a particular fashion. We believe that when attorneys stress the universalist turn, their more vulnerable clients may feel pressured to simply comply with the universalist ethos. Consequently, the lawyer-client interaction becomes a vehicle for imposing the post-racial ethos on persons least inclined to adopt it and either incentivizing or disciplining them to understand their experiences in a particular way.

In summary, we hope that the qualitative data we reveal in support of our theory of postracial hydraulics will make lawyers think more deeply about their role in the racial formation 
process. We recognize that some lawyers have made the universal turn because they believe we are in a post-racial moment. These attorneys honestly believe that we need to move beyond race in understanding social inequality, and universal claims are the best way to achieve this goal. Many, however, do not, and racial formation theory does not have a language for describing the non-ideological endorsement of a particular racial frame. However, here we can see that pragmatics-focused attorneys are engaging in behavior that locks in post-racialism at a discursive and structural level. When attorneys in large numbers change their practice area from Title VII cases to FLSA litigation, they decrease opportunities for plaintiffs to promote an understanding of race and discrimination that would resist post-racialism. Ironically, most of the lawyers we interviewed had not considered the larger, long term market consequences of the shift toward universalist claims. They did not appear to have reflected carefully on whether the changes would become so entrenched that they could not be undone. One might not expect lawyers to engage in this kind of reflection, as some would argue that the daily experience of litigation practice tends to be driven by individual clients' short term needs. Yet lawyers who practice in this area also often have collectivist interests as well, if they are committed to larger justice considerations or even concerns about maintaining a large enough market for employment claims to preserve opportunities for nimble litigation approaches that preserve and capitalize on all available means of victory. Part III will engage with these concerns about individualist versus collectivist practice decisions as part of our discussion of post-racial hydraulics.

\section{Four Post-RACIAL Hydraulics: A Closer LoOK}

Part III explores each of the four post-racial hydraulics introduced earlier in the discussion in more detail. First, we examine the ossification of Title VII doctrine. Second, we consider the larger social effects of making race discrimination appear to lay persons to be a relatively rare problem. Third, we consider how the universal turn will affect plaintiffs' access to justice and the redressability of workplace harms. Finally, we examine issues of client agency and voice that are implicated when attorneys recharacterize discrimination claims as claims under alternative universalist statutes.

\section{A. The Ossification of Title VII and the Particularizing of the FLSA}

In her influential article, The Ossification of American Labor Law, Cynthia Estlund describes the process by which U.S. labor law has ceased to innovate in response to changes in the American workplace. ${ }^{117}$ She labels the present body of labor law "ossified," "moribund," and

\footnotetext{
${ }^{117}$ Estlund, supra note 10 at 1531 ("American labor law has been largely insulated from both internal and external sources of renovation. It has been cut off from revision at the national level by Congress; from "market" -driven competition by employers; from the entrepreneurial energies of individual plaintiffs and the plaintiffs' bar, and the creativity they can sometimes coax from the courts; from variation at the state or local level by representative or judicial bodies; from the winds of changing constitutional doctrine; and from emerging transnational legal norms. Even without knowing where any of these potential paths of change might have led, one can surmise that change or experimentation through one or more of these channels might have produced, over the past half-century, a body of labor law that was more responsive to the very different economic and social conditions that workers and employers face today.").
} 
"largely insulated from both internal and external sources of renovation." "118 The first post-racial hydraulic pressure we identify is a similar dynamic - the ossification of Title VII race discrimination doctrine.

We argue that when particularist discrimination claims are converted into universal claims, Title VII case law stagnates: each time a claim is converted, Title VII loses an opportunity to update its understanding of discrimination and become more responsive to contemporary bias patterns. When a remedial statute becomes outdated in this fashion it loses the confidence of those who rely on its protections. It may be perceived as "ossified," as stubbornly and powerfully resistant to the change it desperately needs. ${ }^{119}$ While some scholars believe that an ossified statute will de-ossify under the proper conditions, others suggest that ossification sets in motion powerful hydraulic currents that result in the claims that are frustrated under the ossified statute reappearing in another form. For example, Ben Sachs has argued that to the extent labor law has ossified, workers' desire for collective action and organizing has been accommodated in Title VII and FLSA litigation. ${ }^{120}$ We are more critical of the hydraulic pressures that convert Title VII claims into FLSA claims because this conversion process creates critical information deficits in the definition of discrimination under Title VII case law that render the statute outdated. Unlike in the labor law arena, these information deficits have larger consequences for our evolving social understanding of race discrimination. To be clear, typically there may be no direct relationship between case law definitions of social phenomena and lay understandings. Title VII however, is a special case. For many Americans, the only guidance they receive about what constitutes workplace discrimination comes in the form of employer education programs programs designed to address existing liability risks as defined by Title VII cases. Therefore, there are more reasons for us to be sensitive to the ossification of Title VII definitions as they are the backdrop against which workplace policies, workplace instruction, and informal workplace norms are defined.

Moreover, in order to understand the special ossification risks we face with Title VII, one needs an understanding of some of the critical changes that have occurred over the last fifty years in the nature of discrimination. Title VII doctrine, at present, is structured in a way that makes it keenly responsive to old style "dominative racism"- the explicit expression of racial prejudice. However, social psychologists and sociologists agree that, to the extent dominative racism still exists, it accounts for a much smaller portion of contemporary discrimination than it did fifty years ago. ${ }^{121}$ Instead, because most Americans embrace equality ideals, they discriminate in masked and sometimes even unconscious ways. Consequently, if Title VII is still going to address discrimination in its modern form, case law and doctrinal tools must be developed to

\footnotetext{
${ }^{118} I d$.

${ }^{119}$ Ben Sachs opines that because labor law has ossified and can no longer nimbly serve contemporary labor movement needs, hydraulic pressures have caused Title VII and FLSA to become vehicles for collective action and organizing. Sachs, supra note 10 at 2686.

${ }^{120} \mathrm{Id}$.

${ }^{121}$ Pearson, et al., supra note 23 (discussing the replacement of dominative racism with other forms of bias, including aversive racism).
} 
create standards for proving discrimination in more subtle forms, including implicit discrimination, aversive discrimination or symbolic discrimination.

This observation is well borne out by our thought experiment, the Heath case. Consider that, even if Heath were brought as a Title VII case, a judge or jury with no experience with subtle discrimination might make little of the employer's decision to effectively segregate the African American workers in the chicken catcher position and subject them to different treatment and lower wages. The judge could easily conclude that existing networks from the era of explicit segregation continued to produce a segregated workforce in the absence of any employer discrimination. The plaintiffs' lawyers in the case would likely not have evidence of explicit discrimination to rebut this claim. Instead they would offer proof of more subtle forms of discrimination that effectively explain the tracking of African Americans into the chicken catcher job. Contemporary subtle forms of bias, such as aversive racism and implicit bias, also could effectively explain why a job that was associated with African Americans was structured to deny workers in that job category the wages and benefits that were normally given to other workers in similarly situated job categories. However, if Title VII ossifies and fails to take on the challenge of establishing these discrimination patterns, it will prove ineffective in a large number of contemporary discrimination cases.

\section{B. Instantiation of Post-Racial Outlook}

We posit that when race discrimination cases are rare, social actors more generally conclude that race discrimination is not a broad scale social problem. Again, while we recognize that there is no clear and direct relationship between case filings and social attitudes, we believe that when a worker rarely hears about race discrimination allegations being made at his place of employment, he is likely to conclude that race is no longer a social barrier at his workplace.

Importantly, the stronger the post-racial ethos becomes, the harder it is for even universal strategies to reach race discrimination problems. Jessica Clarke persuasively argues that universalist legislation and remedies, if they are repeatedly used by minority groups, will become marked and stigmatized as vehicles for minority interest despite their facially universalist language. ${ }^{122}$ One can imagine a similar outcome with respect to the FLSA: if the plaintiffs who bring minimum wage and overtime lawsuits are disproportionately workers of color, the statute, despite its universalist focus, may come to be read as a special interest antidiscrimination measure. Indeed, something of this sort may already be happening, as judges react negatively to the increase in FLSA filings in their courts, labeling the wage and hour claims "nuisance type claims" and calling for Congressional action to amend the FLSA to make wage and hour litigation more difficult for plaintiffs to bring and to win. ${ }^{123}$ One can see that in the post-racial era, the problem of race-based stigmatization does not go away; rather it causes universal or race-neutral methods also to become disfavored. In an atmosphere where minority burdens are

\footnotetext{
${ }^{122}$ Id. at 1271 ("But in many workplaces, even universally available flexible work arrangements and leave policies are regarded as special accommodations for caretakers or "mommy tracks.").

${ }^{123}$ Declaration of Michael Guttentag, Michael Guttentag v. Abercrombie \& Fitch Stores, Inc., Case No. 09-80160CIV-RYSKAMP/VITUNAC (S.D. Fla. March 27, 2009).
} 
not taken seriously, the post-racial outlook begins to cannibalize and undercut even race neutral methods for addressing minorities' discrimination injuries, an ironic result of giving power to universalist arguments.

\section{Access to Justice and the Redressability of Workplace Harms}

Our concerns about plaintiffs' access to justice require us to address the over-arching empirical question of how much the post-racial hydraulic effect is happening - a question that we are pursuing in our larger ongoing empirical project. However, in order to identify the role of post-racial hydraulics in blocking access to justice for potential discrimination plaintiffs, we need to account for the ways in which the imperfect overlap between Title VII and the FLSA causes some discrimination claims to drop out of the market entirely. FIGURE 1 below contemplates four categories of potential plaintiffs. Workers in quadrant 1 are those, like the Heath plaintiffs, who could potentially bring both Title VII and FLSA claims. The potential plaintiffs in quadrant 2 could bring a Title VII claim but have no potential FLSA claim. Those in quadrant 3 have no Title VII claim, but do have an FLSA claim they could bring. Those in quadrant 4 have neither claim type available.

\section{FIGURE 1: Claim Type Availability}

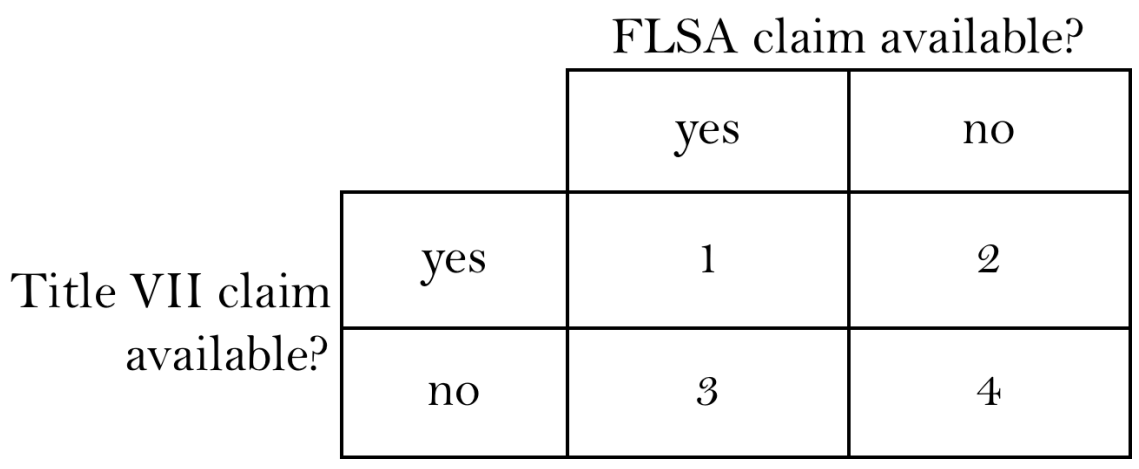

Quadrants 1 and 2 are the most important in discerning the degree to which our theory is supported empirically and determining the effects on plaintiffs' access to justice. (We are not concerned with quadrants 3 and 4, as those potential plaintiffs would have no Title VII claim upon which post-racial hydraulics could act.) In quadrant 1 , a potential plaintiff presents facts to an attorney that could be used to support either or both an FLSA claim or a Title VII claim. If there is a decrease in the number of Title VII claims in this quadrant, or an increase in the number of FLSA claims emerging from this quadrant, our theory is correct.

Similarly, in quadrant 2, where an employee presents facts to support a Title VII claim, but no facts to support an FLSA claim, and the result is fewer Title VII claims filed, our post-racial hydraulics theory would be borne out. Perhaps it is in quadrant 2 that one would observe the real dissonance between the two competing forces of pragmatism and idealism, between the 
individualist pursuit of a "win" and larger collectivist social justice goals. The individualist perspective considers an individual plaintiff's (and attorney's) chance of recovering an award; the collectivist force considers how the making of claims in a particular way affects an entire class of putative plaintiffs in the same circumstance. In quadrant 2, one sees attorneys passing up particularist Title VII claims because they are either unlikely to win or too costly to pursue relative to their opportunity cost of finding other, more viable FLSA claims. This would result in the collective diminution in race discrimination claims that we theorize.

In thinking about the effects on quadrants 1 and 2 in FIGURE 1 , a large-scale shift by attorneys away from Title VII, and toward universalist claims like the FLSA will impede discrimination plaintiffs' access to justice and reduce the ability of workers, particularly lowwage workers, to seek redress for workplace harms. Indeed, if all or even most plaintiffs' employment attorneys take the pragmatic path described by the attorneys above, then wage and hour work will "swallow[] up 100 percent of [their] professional work time"124 and dry up the market for employment discrimination claims. As an empirical matter, little is known about what actually happens to potential discrimination plaintiffs when they are denied representation or have difficulty locating an attorney to represent them. These claims may simply not be brought or be brought pro se. Yet if plaintiffs decide to represent themselves, their prospects are likely worse than if they were able to secure representation. ${ }^{125}$ Alternatively, other lawyers may enter to fill the vacuum as plaintiffs' employment lawyers shift their practices away from Title VII claims. That is, if some lawyers are electing not to take cases in quadrant 2 in FigurE 1, other lawyers may enter the market to meet this demand. Though we hypothesize that many such cases never make their way to court, contributing to the downturn in Title VII case filings observed by Clermont and Schwab and shown in Appendix A, we acknowledge that more empirical work is required in this area to better map these trends onto the options presented in FIGURE $1 .^{126}$ Indeed, without more information about the availability of alternative claims, little may be gleaned from the available empirical analyses about case filings and win rates.

\footnotetext{
${ }^{124}$ Borgen, supra note 105 (noting also that the shift to FLSA litigation "provided an opportunity to diversify our firm's practice which had, until then, been almost exclusively limited to Title VII class action litigation"); see also Deering, supra note 102 (commenting from a defense perspective, "The very early 2000s was when I really began handling FLSA cases in earnest... FLSA litigation, including class and collective actions, easily consumes better than half my practice time now.").

${ }^{125}$ In Nielsen, Nelson and Lancaster's study of federal employment discrimination litigation, "one in five plaintiffs act[ed] as his or her own lawyer, operating pro se over the course of the lawsuit." These plaintiffs were "almost three times more likely [than plaintiffs with legal representation] to have their cases dismissed, [were] less likely to gain early settlement, and [were] twice as likely to lose on summary judgment." Nelson, Nielsen \& Lancaster, supra note 41. Selection effects, however, make it difficult to use these figures to learn anything about how well pro se plaintiffs fare holding constant the viability of the evidence supporting their claims. In other words, pro se plaintiffs may bring cases that are weaker on the merits. As an anecdotal example, Eigen defended several employers against claims brought by pro se plaintiffs. In his estimation, these cases were extremely weak and generally unsupported by facts. In at least two instances, Eigen suspected the pro se plaintiffs of being significantly mentally unstable.

${ }^{126}$ For example, is it theoretically possible that fewer cases are being filed in federal court, but that more plaintiffs are participating in each case, producing little or no drop in the actual number of people being represented. However, the fact that much of federal courts' hostility toward Title VII cases has taken the form of adverse decisions in class action cases such as Wal-Mart may cast doubt on this possibility.
} 
Post-racial hydraulics also present significant problems for the plaintiffs who secure representation, but end up with FLSA rather than Title VII claims (those in FIGURE 1, quadrant 1). Here it is often only the relatively higher-paid plaintiffs with higher-value claims who proceed under the FLSA. ${ }^{127}$ Though the chicken catcher plaintiffs in Heath were low-wage workers, they are the exception: most FLSA cases filed today are on behalf of plaintiffs who occupy relatively higher-paid, higher-skilled jobs. ${ }^{128}$ This can be explained by the incentives that the FLSA creates for both workers and attorneys, which skew representation in favor of workers who hold jobs that are at the higher end of the labor market.

Though the FLSA attempts to encourage workers to file suit in a variety of ways, ${ }^{129}$ an FLSA claim may still provide only a low dollar recovery, at great cost, for some categories of plaintiffs. The lower the worker's wage, the lower the value of the claim. ${ }^{130}$ And to actually achieve a recovery for that relatively low-value claim, a worker faces what can be a lengthy, costly, and uncertain litigation process, during which she may risk losing her job in retaliation for her lawsuit (if she is suing her present employer). "Against these costs, the benefits of claiming appear paltry," and rational low-wage plaintiffs may choose to forego filing a FLSA claim as a substitute for Title VII. ${ }^{131}$

${ }^{127}$ Alexander (2014), supra note 14.

${ }^{128}$ Id.

129 The FLSA offers plaintiffs liquidated, or double damages, attorneys' fees and costs, and protection against retaliation. 29 U.S.C. $\$ 201$ et seq; 29 U.S.C. \$216(b); 29 U.S.C. § 215(a)(3). One of us has referred to these elsewhere as "operational rights," or the "set of protections and inducements [offered by workplace laws] to entice workers to become law enforcers." Charlotte S. Alexander \& Arthi Prasad, Bottom-Up Workplace Law Enforcement: An Empirical Analysis, 89 IND. L.J. 1069, 1073 (2014) (noting that "these incentives are miscalibrated in the case of many low-wage, front-line workers, whose fear of retaliation or doubt in the efficacy of complaining outweigh the benefits that would accrue from workplace law enforcement").

${ }^{130}$ This is because the starting point for calculating the value of a FLSA claim for a low-wage worker is usually a very low number: a wage shortfall of less than $\$ 7.25$ per hour for minimum wage claims or an overtime claim that is calculated on the basis of the plaintiff's regular "straight time" hourly wage. Recovery for Title VII claims, by contrast, is not entirely indexed to the worker's wage. A claim for back pay after a discriminatory termination, demotion, or promotion denial, for example, is keyed to the amount of pay that the plaintiff lost. However, judges and juries may also award compensatory damages for non-economic losses such as emotional distress, which are generally unavailable under the FLSA except in cases of retaliation, as well as punitive damages. Richards v. Canyon Cnty., CV 12-00424-S-REB, 2014 WL 1270665 (D. Idaho Mar. 26, 2014) ("Congress has chosen to do so in other employment discrimination settings, such as the 1992 amendments to the types of damages available in a Title VII claim, to add punitive damages and damages for emotional distress.”); Bogacki v. Buccaneers Ltd. P'ship, 370 F. Supp. 2d 1201, 1202 (M.D. Fla. 2005) (discussing availability of non-economic FLSA damages). Thus, even though Title VII damages are subject to statutory caps, they may still exceed those available under the FLSA on a per-plaintiff basis, because they are meant to compensate for a broader swath of injuries, and are not entirely determined by the worker's sometimes extremely low hourly wage.

${ }^{131}$ Alexander \& Prasad, supra note 129 at 1106 (noting that "[t] hough back pay may be available to a plaintiff at the end of a lawsuit, if that amount is insufficiently large - and for plaintiffs who sue because they were paid less than the minimum wage, back pay awards will, by definition, be quite small - then enduring the uncertain, stressful, drawn-out process of litigation may not be worth it" and reporting the results of surveys of low-wage workers that "workers doubt the certainty of the benefit they might receive from claims making: the second-most frequent reason for workers' choices not to make claims was that workers doubted their claims would make any difference"). 
Moreover, if many FLSA plaintiffs with individual small-dollar claims seek to reduce the costs of litigation by aggregating their claims into a single lawsuit, the statute's collective action mechanism creates even more barriers to participation. Unlike in a typical class action brought under Fed. R. Civ. P. 23, each individual plaintiff in a FLSA case must affirmatively opt into the case. ${ }^{132}$ This erects multiple barriers to participation: potential plaintiffs may never receive a notice about a FLSA suit; the notice may be written in indecipherable legalese; the prospect of participating in a lawsuit may appear too costly, lengthy, intimidating, futile, or dangerous. ${ }^{133}$ With respect to the danger of retaliation, low-wage workers and those without documented immigration status in particular may be especially reluctant to take the very public step of affirmatively opting into a lawsuit against their employer. ${ }^{134}$ Therefore, because the default in a FLSA lawsuit is set at non-participation, and plaintiffs must take affirmative steps to opt in, there are barriers to entry. ${ }^{135}$

${ }^{132}$ Id

${ }^{133}$ Alexander (2010), supra note 1 at 469-70 (exploring the litany of reasons that a potential plaintiff may not opt into a FLSA collective action); Zev J. Eigen, How to Reduce Mass FLSA Violations using Cheap, Available Technology, The Regulations of Compensation: Proceedings of the NYU $66^{\mathrm{TH}}$ AnNUAL ConfERENCE ON LABOR (C. Rosado, ed.) (2014) (same).

${ }^{134}$ Studies have found that fear of retaliation in low-wage workplaces is widespread and many unscrupulous employers appear unmoved by the FLSA's prohibition on such reprisals; workers may therefore have direct knowledge of or experience with the weakness of the FLSA's retaliation protections and make the choice to keep their jobs instead of risking their livelihood for an uncertain future payout. Alexander \& Prasad, supra note 129 at 1089 ("Of the $43 \%$ of workers who decided not to make a claim about an identified workplace problem, the top two reasons workers gave for their decision were a fear of being fired and a belief that the claim would make no difference. The next two reasons (apart from "other") were also retaliation related: the worker's fear of having her wages or hours cut and the worker's knowledge of retaliation against others for claiming behavior."); id. at 1092 ("[O]f all workers who had made claims about justiciable workplace problems, about $15 \%$ experienced unlawful retaliation, $28 \%$ experienced some other form of reprisal, another $15 \%$ had their claims addressed or promised to be addressed, and $42 \%$ were met with employer inaction or some other response.").

${ }^{135}$ RICHARD H. THALER \& CASS R. SUNSTEIN, NUDGE 83 (2008) (discussing default rules and noting that "many people will take whatever option requires the least effort, or the path of least resistance .... [F]or a given choice there is a default option--an option that will obtain if the chooser does nothing--then we can expect a large number of people to end up with that option, whether or not it is good for them."). A study by one of the present authors of 250 FLSA cases filed as collective actions in the U.S. District Court for the Southern District of Florida bears this out, showing a median opt in rate of only fifteen percent, meaning that eighty-five percent of the workers who could have joined FLSA litigation did not do so. Alexander (2010), supra note 1 at 466 ("Plaintiff opt in rates in these cases ranged from $0 \%$ to $48 \%$, with a median of $15 \%$."). In contrast, the opt out structure of Rule 23 under which Title VII class actions are brought both encourages plaintiff participation and provides a measure of protection against employer retaliation. There, class members who fall within a court-approved class definition are automatically included in the litigation unless they opt out. (Of course, as the plaintiffs' attorneys interviewed above commented, achieving court approval to proceed as a class in the first place is no small feat. The Rule 23 class action mechanism is not perfect, but the FLSA collective action mechanism may be a less viable alternative in operation, particularly for low-wage or undocumented workers who lack resources and are extremely vulnerable to retaliation, than it initially appears to be.) A small number of plaintiffs must act as class representatives, thereby revealing their identities to the court and the defendant, but the bulk of the class members can remain anonymous until the very end of litigation when a settlement or judgment is distributed. Even then, collection of one's portion of the damages is unlikely to prompt retaliation by the defendant, as presumably many class members are doing the same, and it may be less likely that an employer would fire a large number of workers en masse. 
The same set of factors that may dissuade low-wage workers from filing or joining a FLSA case may also lower the incentives for plaintiffs' lawyers to accept and fully pursue these workers' claims. Attorneys may decline representation of workers whose wage shortfalls are too insignificant to be worth the lawyers' time and attention. ${ }^{136}$ Alternatively, plaintiffs' lawyers may adopt a "high-volume, small case, quick-settlement" model, in which they accept many individual FLSA cases but do little except file a form complaint before agreeing to a nuisance settlement. ${ }^{137}$ This model, while providing some plaintiff representation, provides little in the way of recovery of damages, and may contribute to some judges' increasing frustration with the boom in FLSA litigation, discussed further below.

Thus, post-racial hydraulics may be particularly problematic for the least powerful groups in the workplace - those who lack the knowledge, time, and resources to opt into a FLSA lawsuit; those who fear retaliatory job loss for suing their employer; and those who would bring low-dollar claims for unpaid minimum wages. Many workers who fall into these categories are the same workers who would be traditionally protected by antidiscrimination mandates. ${ }^{138}$ These workers might therefore lose their particularist claim for discrimination under Title VII at the hands of pragmatic plaintiffs' employment lawyers, but then also find it difficult to enforce a universalist claim under the FLSA, for all of the very same reasons that they need protections on the job in the first place. ${ }^{139}$

\section{Client Agency}

Our final concern centers on the potential that lawyer influence, rather than client choice, is the primary driver behind the shift toward universalism. We wondered whether lawyers were preemptively categorizing claims as FLSA claims before presenting plaintiffs with the option of filing a particularist Title VII race discrimination claim. Alternatively, lawyers might present both the Title VII and FLSA option, but strongly suggests to their clients that they would be financially better off if they converted their claims into FLSA claims. Relatedly, we questioned whether plaintiffs who agreed to have their discrimination claims converted to FLSA claims felt they had lost anything in the process. Would these FLSA plaintiffs have same sense of justice

\footnotetext{
${ }^{136}$ Interview, supra note 109 ("It has become so expensive to try cases that it is really hard to actually litigate the individual cases, in my opinion. I can't speak for everyone but my experience is that many individual wrongful termination cases are being turned down and it is hard for those people to find excellent attorneys to take the cases.").

${ }^{137}$ Alexander (2010), supra note 1 at 458 ('In fact, the FLSA's opt in requirement may actually decrease plaintiffs' recoveries in relation to attorneys' fees: instead of engaging in the expensive notice and opt in process, many plaintiffs' attorneys have adopted a high-volume, small-case, quick-settlement approach that compensates them for their investment in the case but delivers only a minimal settlement to the plaintiffs.").

${ }^{138}$ Zatz, supra note 69 at 6 (theorizing about the commonalities between anti-discrimination and minimum wage law).

${ }^{139}$ In fact, many workers at the bottom of the wage scale might not be covered by the FLSA at all, so would have no substitute FLSA claim in the first place. Some home care and domestic workers, as well as agricultural workers, are exempt from the minimum wage requirement, overtime requirement, or both, as are workers who fall into the statute's many other exemptions. Charlotte S. Alexander, Anna Haley-Lock \& Nantiya Ruan, Stabilizing Low-Wage Work, 50 HARV. C.R.-C.L. L. REV. (forthcoming 2015).
} 
after a victory as if they had found an attorney willing to assist them with filing a Title VII claim?

When the process of post-racial hydraulics substitutes a universalist FLSA claim for a particularist Title VII claim, there is a mismatch between naming and claiming - the plaintiff may recover for some harm that she suffered, but not for the particular harm that first brought her to a lawyer's office. ${ }^{140}$ Cognitive dissonance should be expected when the plaintiff understands her injury as being produced by discrimination but never receives any judicial finding that establishes the validity of her perspective. ${ }^{141}$ Certainly, plaintiffs are not agency-less pawns directed by their attorneys. Certainly, some plaintiffs will prefer the substitution of a universalist claim for a particularist one. However, their reasons for preferring universalism may stem from disturbing factors that we should disrupt rather than accept as a matter of course. Numerous studies in social psychology show that workers who complain of race or sex discrimination in the workplace are generally disliked by coworkers and managers, even when conditions suggest that race or sex bias clearly played a role in their adverse treatment. ${ }^{142}$ Given the real costs associated with claiming discrimination, discrimination plaintiffs may be relieved to have their claims converted to a universal form. For if they actually litigate particularist race discrimination

\footnotetext{
${ }^{140}$ Noah Zatz offers an alternative view of the minimum wage as itself a civil rights protection. This account makes some progress toward harmonizing the differences among Title VII and FLSA claims that we identify. In Zatz's view, FLSA violations might act as a sort of disparate impact claim (though he does not use that particular explanatory framework): "The basic idea here is that sufficiently low wages indicate that the worker's earnings have been suppressed by morally arbitrary factors (including but not limited to race and sex), even if those factors cannot be identified with precision in the individual case. Requiring an employer to pay supra-market wages is like making an employer provide an accommodation that allows an employee to work as productively as if she had no (morally arbitrary) impairment." Zatz, supra note 69 at 8 . Instead of seeing a FLSA claim as an inadequate replacement for a Title VII claim, this view might see the FLSA as an additional, complementary tool for uncovering the effects of latent racism, sexism, or other form of discrimination.

${ }^{141}$ As William Felstiner, Richard Abel, and Austin Sarat, who offer that, in order for a problem to be transformed into a legal claim, a person must first "say[] to [her]self that a particular experience has been injurious," or name it; she then "attributes [the] injury to the fault of another individual or social entity;" or assigns blame; she then addresses her complaint "to the person or entity believed to be responsible and asks for some remedy," or makes a claim. William L.F. Felstiner, Richard L. Abel \& Austin Sarat, The Emergence and Transformation of Disputes: Naming, Blaming, Claiming ..., 15 LAW \& SOC'Y REV. 631, 635-36 (1980-81). In a Title VII case, the plaintiff says, in effect, "Discrimination happened to me. I suffered as a result, and my employer was at fault. This is the reason I am suing." Even if the plaintiff does not win, her lawsuit nevertheless attempts to, as Cass Sunstein says, "change the social meaning of action through a legal expression or statement about appropriate behavior." Cass R. Sunstein, On the Expressive Function of Law, 144 U. PA. L. REV. 2021, 2031 (1996).

${ }^{142}$ Employees recognize that persons who claim discrimination are socially disfavored. Managers and coworkers have negative reactions to persons whom allege discrimination, whether or not there is strong evidence to suggest that discrimination occurred. See Cheryl Kaiser \& Carole T. Miller, Stop Complaining: The Social Costs of Making Attributions to Discrimination 27 PERS. SOC. PSYCH. Bull. 254 (2001) (summarizing results of study in which test takers made attributions to low score to discrimination to those in which subject did not). Even in cases where discrimination was readily apparent, reviewers rated the persons who complained of discrimination lower on favorability scales than those who did not make claims of racism. Cheryl R. Kaiser, Derogating the Victim, The Interpersonal Consequences of Blaming Events on Discrimination 6 Group Processes Intergroup Relations 10 (2003). (discussing same in interview context). The authors conclude that the social costs of discrimination may discourage victims from coming forward.
} 
claims, they risk going back to a workplace where they may be marginalized or seen by management and coworkers as hypersensitive, unlikeable troublemakers. ${ }^{143}$

Barbara Trepagnier provides context in her book Silent Racism, ${ }^{144}$ for understanding why Americans mistreat people who complain of discrimination. She explains that for many individuals a key part of their self esteem is maintaining a non-racist image. Consequently, when individuals encounter people who would accuse them of racially biased behavior and destroy their sense of positive self image, they attempt to sanction the accuser. In particularly explosive moments, people may erupt into what one author has called "post-racial rage" at the suggestion that they have been racially biased or insensitive. ${ }^{145}$ That is, in the post-racial era many whites are publically committed to racial equality as a general matter, but they are also very angry and frustrated when people reveal that seemingly race neutral and "fair" arrangements have discriminatory effects and consequences. Cho makes similar observations that further flesh out the concept of "[p]ost racial rage." As Cho explains, ["u]nder postracialism, race does not matter, and should not be taken into account or even noticed. Thus, one who points out racial inequities risks being characterized as an obsessed-with-race racist who is unfairly and divisively 'playing the race card'--one who occupies the same moral category as someone who consciously perpetrates racial inequities." ${ }^{46}$

Despite these facts, some individuals may still feel it is important to name discrimination when they see it and may feel that their injury is more significant when accurately named as a civil rights violation. ${ }^{147}$ Consequently, some plaintiffs may feel that they have lost their voice if they are speaking to the court in terms of pay stubs and hours worked instead of acts of and resistance to discrimination. ${ }^{148}$ In short we theorize that the replacement of a Title VII discrimination claim with a FLSA claim may rob the plaintiff of her voice, her ability to name the particular reason that she was harmed - her sex, her race, her national origin, her color, or her religion. $^{149}$

\footnotetext{
${ }^{143}$ See, e.g., Alexander Czopp and Margo Monteith, Confronting Prejudice(Literally): Reactions to Confrontations of Racial and Gender Bias, 29 PERS. \& SOC. PSYCH. Bull 532 - 544 (2003) (explaining that when minority targets complained of discrimination there was greater risk that they were perceived as "overreacting" than when nonminorities identified behavior as racially discriminatory); Donna M. Garcia, Perceivers Responses to In-Group and Out-Group Members Who Blame a Negative Outcome on Discrimination, PERS. \& SoC. PSYCH. BULL 769, 770-771 (2005).

144 Barbara Trepagnier, Silent Racism: How Well-Meaning White People Perpetuate the RaCial Divide (2010).

${ }^{145}$ Camille Gear Rich, Race, Gender and Sexual Expression Presentation (October 2014).

${ }^{146}$ Cho, supra note 2 at 1594-95.

${ }^{147}$ See, e.g. Bagenstos, supra note 13 at 114 (noting that "the 'civil rights' label has a powerful cachet in American politics").

${ }^{148}$ However, whether even Title VII claims adequately allow plaintiffs to tell their stories is open to question. See, e.g., Herbert A. Eastman, Speaking Truth to Power: The Language of Civil Rights Litigators, 104 YALE L.J. 763, 767-68 (1995) (noting the shortcomings of civil rights pleading as a story-telling device for plaintiffs).

${ }^{149}$ See, e.g., Binny Miller, Give Them Back Their Lives: Recognizing Client Narrative in Case Theory, 93 MicH. L. REV. 485, 486 (1994) (describing theorists in the vein of "critical lawyering" who "posit that client voices have been muted by the narratives that lawyers tell on their behalf").
} 


\section{CONCLUSION}

Our discussion of post-racial hydraulics is designed to render visible some of the long term consequences of the "universal turn" in employment litigation. While we suspect that the post-racial hydraulics we identify may be at work in other areas of law in which universalism has been urged, in this Article, we identify this dynamic as it emerges in the transition from Title VII race discrimination to FLSA litigation. When litigators turn to universalism as a pragmatic, strategic choice, rather than because of faith in the substantive ideology that informs this outlook, they strengthen the persuasive hold that post-racialism already has on segments of the American public; discipline plaintiffs to re-interpret their injuries in a race neutral fashion; and cause Title VII case law on race to stagnate in ways that make it more difficult to bring future race discrimination claims. We attempt to provide readers with some understanding of the theoretical significance of this development, as well as the practical real world consequences of the shift, in terms of employees' access to justice and agency in shaping the legal claims that are brought to court in their name.

This article leaves some questions unanswered. In this piece our goal was to collect and mine enough qualitative data to identify and map the post-racial hydraulics we intend to study in greater depth in future research. This project, therefore, was a necessary precondition to the broader qualitative and quantitative study that will follow. Our preliminary data here only provide for limited observations, and some speculation about the likely global effects if these hydraulics continue to operate and grow as we have observed them. Our early review of national data suggests that these hydraulics may be operating in an escalated fashion in certain jurisdictions, but we cannot at this juncture offer any certainty about how broadly this occurs in other jurisdictions. In our next project, we address these larger questions. Our next round of research will be devoted to examining civil rights employment case filing statistics in greater depth, along with other possible universalist claims apart from the FLSA. We also will use additional attorney surveys and interviews to better explore the mechanisms behind post-racial hydraulics, investigating whether, how, and when plaintiffs' attorneys have shifted their caseloads away from discrimination litigation and toward other sources of relief for workers.

Our discussion began with a creation story, and it ends with one as well. Literature and film are stocked with creation stories in which the creator's vision is realized, but her failure to fully consider the consequences of what she has wrought yields dire results. ${ }^{150}$ The message behind these literary examples holds true here as well. One should not create something simply because of its ease or expedience. Rather, creators have political, moral, and ethical obligations that should control their decisions as to what to create, when, and why. Our goal in this discussion was to draw greater attention to the lawyer's role as creator, and to give lawyers pause as they turn away from discrimination claims in favor of universal ones, to allow them to consider the greater collectivist impact caused by the pursuit of an individual win. With more

\footnotetext{
${ }^{150}$ See, e.g., MARy Shelley, Frankenstein, OR, The MOdern Prometheus (1817) (describing creation of Frankenstein monster and unexpected destruction wrought by the creature because of alienation and loneliness); 2001: A SPACE ODYSSEY (describing destruction wrought by self aware computer designed to protect spaceship occupants).
} 
information and time for reflection, attorneys may view universalist strategies with a bit more skepticism, for, if they fail to heed the lessons offered here, they may find that post-racialism overtakes us sooner and for much longer than they might otherwise expect. 


\section{APPENDIX A: CHARTING SHIFTS IN EMPLOYMENT DisCRIMINATION AND FLSA LiTIGATION}

Using data from the Administrative Office of the U.S. Courts, FIGURE 2 charts the number of employment discrimination and FLSA cases filed by private plaintiffs in all U.S. district courts between 1977 (the year that a separate "civil rights employment" category was first used to track case types) and 2013 (the most recent complete year of available data).

Figure 2: Total Private Civil Rights Employment and FLSA Cases Filed, All U.S. District Courts, Federal Fiscal Years 1977-2013

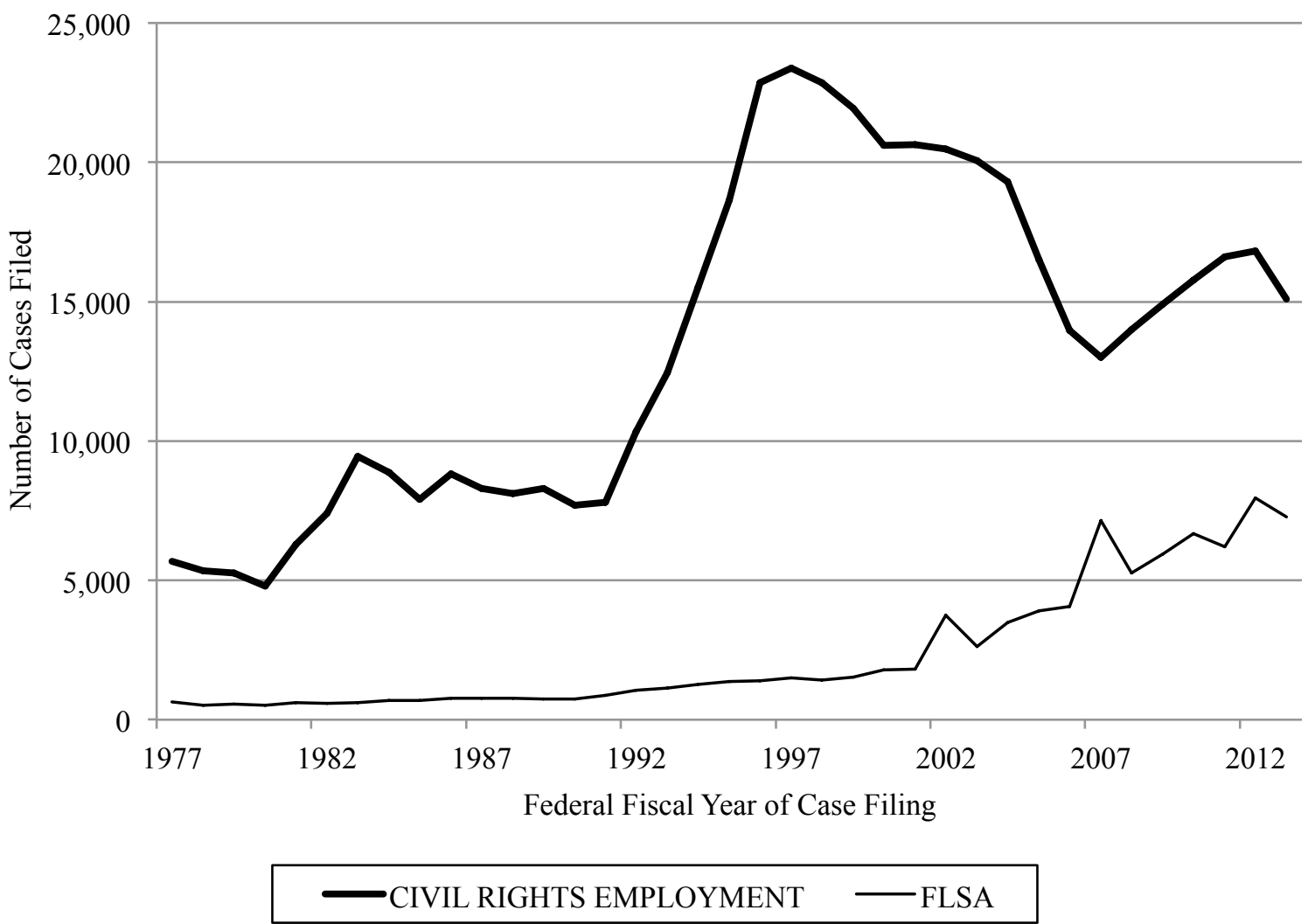

As FiguRE 2 shows, the number of employment discrimination cases filed each year dropped from a high of 23,392 in 1997 to 15,108 in 2013 , a thirty-five percent decrease. ${ }^{151}$ In

151 Other commentators have noted the same drop in employment discrimination cases on federal courts' dockets. See, e.g., Clermont \& Schwab (2009), supra note 40 at 117 (noting that the number of workplace discrimination cases disposed of by federal district courts had experienced a "startling drop" in the late 1990s and early 2000s). Clermont and Schwab noted a peak in employment discrimination case terminations in 1998; it follows that a peak in filings (which Figure 1 captures) would register in the data in years prior to the termination peak, to account for the time it takes for a case to reach disposition after it is filed. Id. at 117 (noting that "the employment discrimination category has dropped in absolute number of terminations every year after 1998"). One of the present 
contrast, FLSA case filings held relatively steady from 1977 until around 2000, and then began to increase rapidly through 2013. The total number of FLSA cases filed in $2013(7,266)$ was $307 \%$ higher than the number filed in 2000 (1,786), when the trend line began its rise, and 388\% higher than the number of cases filed in $1997(1,490)$, the year of the civil rights employment case filing peak. ${ }^{152}$

FIGURE 2 draws on data from the Administrative Office of the United States Courts, which collects a variety of case filing statistics per federal fiscal year (October 1 through the following September 30). ${ }^{153}$ These statistics categorize cases by "Nature of Suit" (NOS) code, a designation taken from the civil cover sheet that plaintiffs or their attorneys must complete when

authors has also found consistent reductions in charges of discrimination filed with the Equal Employment Opportunity Commission between 1992 and 2012. David S. Sherwyn, Michael Heise, and Zev J. Eigen, Experimental Evidence that Retaliation Claims are unlike other Employment Discrimination Claims, 44 SETON HALl L. REV. 455 (2014) (analyzing Equal Employment Opportunity Commission case filing data, and finding consistent linear percentage reductions in discrimination claims filed from 1992 to 2012).

${ }^{152}$ Though it is not the project of this Article to identify specific events that might explain each peak and valley of the 1997-2013 civil rights employment case filing trend line, a few are notable. Moving from left to right, case filing numbers rose sharply in 1991, possibly in response to that year's Civil Rights Act liberalizing many of Title VII's substantive and procedural requirements. See, e.g., Clermont \& Schwab (2009), supra note 40 at 116 (noting that "the Civil Rights Act of 1991 made Title VII law more favorable to plaintiffs, increasing the propensity to sue; its changes included a right to jury trial and the availability of compensatory and punitive damages"). The reason for the timing of the 1997 peak is less clear, though it may be attributed to a number of court decisions around that time that created procedural barriers for discrimination plaintiffs. See, e.g., Melissa Hart, Will Employment Discrimination Class Actions Survive?, 37 AKRON L. REV. 813, 831 (2004) (describing decisions in the late 1990s in which courts "essentially concluded that the Civil Rights Act of 1991 had sufficiently changed the landscape of Title VII so that claims under the Act could no longer be brought as class actions under the Federal Rules of Civil Procedure"). Figure 1 also shows a temporary increase in civil rights employment case filings beginning in 2007. This is perhaps the result of class actions' being removed to federal court from state court in the aftermath of the 2005 Class Action Fairness Act, which enabled such removals. The drop in filings in 2012, in turn, could be explained by the Supreme Court's 2011 decision in Wal-Mart Stores, Inc. v. Dukes, 131 S. Ct. 2541 (2011), which made Title VII class actions significantly harder for plaintiffs to prove in instances where employers delegate extensive authority to managers and exercise less centralized control over employment decision making. The FLSA trend line shows fewer dramatic peaks and valleys than the civil rights employment line, but there are two appreciable spikes in case filings in 2000-2002 and 2006-2007. In a separate empirical project analyzing over 50,000 FLSA cases filed in federal court between 2000 and 2011, one of the present authors has identified hundreds of separate FLSA cases that were filed against a number of public school districts in the U.S. District Court for the Southern District of Mississippi, accounting for the 2000-2002 spike in FLSA case filings. A similar cluster of thousands of FLSA cases were filed against Dolgencorp., Inc., the corporate parent of Dollar General Stores, in the U.S. District Court for the Northern District of Alabama in 2006-2007. Charlotte S. Alexander, An Empirical Portrait of Federal Wage and Hour Litigation, supra note 14.

${ }^{153}$ Specifically, figures come from the Administrative Office's annual Table C-2, "Cases Commenced, by Basis of Jurisdiction and Nature of Suit." For the years 1997-2013, the tables are available on the Administrative Office's website at http://www.uscourts.gov/Statistics/JudicialBusiness/archive.aspx. Hard copy versions of the tables for the years 1977-1996 are on file with the authors. Table C-2 groups cases into "Private Cases," which are split further into three columns reflecting bases of jurisdiction, and "U.S. Cases," split into two columns for cases in which the United States was a plaintiff and a defendant. The case filing totals we used are the sum of all "Private Cases" filed, plus cases in which the United States was a defendant - cases in which the plaintiffs would, by definition, have been private. We exclude cases in which the United States was a plaintiff because of our focus on private plaintiffs' attorneys' motivations around case and claim selection. (We do not contend that government attorneys are completely immune to the post-racial hydraulic pressures that we describe, just that their motivations and incentives likely vary from those of private plaintiffs' attorneys in significant ways.) 
filing a case. ${ }^{154}$ Plaintiffs are given a menu of NOS codes and must choose one that captures the core claims of their case; clerks' office staff record NOS codes and other data on federal courts' caseloads that are then combined and tabulated by the central Administrative Office.

FIGURE 2 covers federal fiscal years 1977, the first year that a "civil rights employment" NOS code was available, through 2013, the most recent complete year of available data. Throughout that period, the NOS code assigned to FLSA cases (710) remained the same. The civil rights employment NOS code (442) remained the same from 1977 to 2008, when an additional code (445) was carved out of 442 for Americans with Disabilities Act ("ADA") employment discrimination cases. (Previously, ADA cases were either categorized under 442 or under a separate "Other Civil Rights" code. Other cases categorized under 442 include those brought under Title VII of the Civil Rights Act of 1964, the Age Discrimination in Employment Act, and 42 U.S.C. $§ ~ 1981$.$) FIgURE 2$ uses case filing totals for NOS code 442 for 1977-2007 and for 2008-2013, combines totals for NOS codes 442 and $445 .^{155}$

Appendix B lists the Administrative Office case filing figures for federal fiscal years 1977-2013, showing the sub-totals and totals on which FIGURE 2 relies.

Appendix B: U.S. Courts Administrative Office Case Filing Data

\begin{tabular}{|c|c|c|c|c|c|c|c|c|}
\hline \multirow[b]{3}{*}{ YEAR } & \multirow{2}{*}{\multicolumn{3}{|c|}{ FLSA }} & \multicolumn{5}{|c|}{ CIVIL RIGHTS EMPLOYMENT } \\
\hline & & & & \multirow[b]{2}{*}{ TOTAL } & \multicolumn{2}{|c|}{$\begin{array}{l}\text { Civil Rights } \\
\text { Employment }\end{array}$} & \multicolumn{2}{|c|}{ ADA Employment } \\
\hline & TOTAL & $\begin{array}{l}\text { U.S. as } \\
\text { Defendant }\end{array}$ & $\begin{array}{l}\text { Private } \\
\text { Cases }\end{array}$ & & $\begin{array}{l}\text { U.S. as } \\
\text { Defendant }\end{array}$ & $\begin{array}{l}\text { Private } \\
\text { Cases }\end{array}$ & $\begin{array}{l}\text { U.S. as } \\
\text { Defendant }\end{array}$ & $\begin{array}{l}\text { Private } \\
\text { Cases }\end{array}$ \\
\hline 1977 & 634 & 40 & 594 & 5,685 & 592 & 5,093 & - & - \\
\hline 1978 & 518 & 29 & 489 & 5,343 & 493 & 4,850 & - & - \\
\hline 1979 & 558 & 26 & 532 & 5,269 & 465 & 4,804 & - & - \\
\hline 1980 & 519 & 23 & 496 & 4,796 & 402 & 4,394 & - & - \\
\hline 1981 & 603 & 24 & 579 & 6,290 & 667 & 5,623 & - & - \\
\hline 1982 & 588 & 15 & 573 & 7,397 & 627 & 6,770 & - & - \\
\hline 1983 & 615 & 15 & 600 & 9,443 & 811 & 8,632 & - & - \\
\hline 1984 & 681 & 27 & 654 & 8,883 & 649 & 8,234 & - & - \\
\hline 1985 & 688 & 26 & 662 & 7,916 & 744 & 7,172 & - & - \\
\hline 1986 & 782 & 21 & 761 & 8,828 & 865 & 7,963 & - & - \\
\hline 1987 & 778 & 36 & 742 & 8,288 & 954 & 7,334 & - & - \\
\hline 1988 & 759 & 22 & 737 & 8,103 & 867 & 7,236 & - & - \\
\hline
\end{tabular}

\footnotetext{
${ }^{154}$ Civil Cover Sheet, Form JS 44 (Rev. 12/12), http://www.uscourts.gov/uscourts/FormsAndFees/Forms/JS044.pdf.

${ }^{155}$ Admittedly, this procedure may miss some pre-2008 ADA employment cases that were categorized as "Other Civil Rights" rather than NOS code 442. Clermont and Schwab note similar issues with comparing Administrative Office codes over time, noting that "the coding is not perfect." Clermont \& Schwab (2009), supra note 40 at 104 n.4. In any event, as the table in Appendix B shows, the number of ADA employment discrimination cases at issue is quite small.
} 


\begin{tabular}{|c|c|c|c|c|c|c|c|c|}
\hline \multirow[b]{3}{*}{ YEAR } & \multirow{2}{*}{\multicolumn{3}{|c|}{ FLSA }} & \multicolumn{5}{|c|}{ CIVIL RIGHTS EMPLOYMENT } \\
\hline & & & & \multirow[b]{2}{*}{ TOTAL } & \multicolumn{2}{|c|}{$\begin{array}{l}\text { Civil Rights } \\
\text { Employment }\end{array}$} & \multicolumn{2}{|c|}{ ADA Employment } \\
\hline & TOTAL & $\begin{array}{l}\text { U.S. as } \\
\text { Defendant }\end{array}$ & $\begin{array}{l}\text { Private } \\
\text { Cases }\end{array}$ & & $\begin{array}{l}\text { U.S. as } \\
\text { Defendant }\end{array}$ & $\begin{array}{l}\text { Private } \\
\text { Cases }\end{array}$ & $\begin{array}{l}\text { U.S. as } \\
\text { Defendant }\end{array}$ & $\begin{array}{l}\text { Private } \\
\text { Cases }\end{array}$ \\
\hline 1989 & 741 & 25 & 716 & 8,299 & 931 & 7,368 & - & - \\
\hline 1990 & 735 & 14 & 721 & 7,687 & 845 & 6,842 & - & - \\
\hline 1991 & 861 & 19 & 842 & 7,806 & 717 & 7,089 & - & - \\
\hline 1992 & 1,065 & 17 & 1,048 & 10,331 & 827 & 9,504 & - & - \\
\hline 1993 & 1,124 & 12 & 1,112 & 12,465 & 872 & 11,593 & - & - \\
\hline 1994 & 1,275 & 24 & 1,251 & 15,526 & 1,097 & 14,429 & - & - \\
\hline 1995 & 1,367 & 20 & 1,347 & 18,649 & 1,275 & 17,374 & - & - \\
\hline 1996 & 1,390 & 19 & 1,371 & 22,863 & 1,209 & 21,654 & - & - \\
\hline 1997 & 1,490 & 25 & 1,465 & 23,392 & 1,241 & 22,151 & - & - \\
\hline 1998 & 1,412 & 29 & 1,383 & 22,860 & 1,320 & 21,540 & - & - \\
\hline 1999 & 1,518 & 26 & 1,492 & 21,941 & 1,326 & 20,615 & - & - \\
\hline 2000 & 1,786 & 21 & 1,765 & 20,607 & 1,362 & 19,245 & - & - \\
\hline 2001 & 1,827 & 27 & 1,800 & 20,641 & 1,270 & 19,371 & - & - \\
\hline 2002 & 3,760 & 25 & 3,735 & 20,491 & 1,266 & 19,225 & - & - \\
\hline 2003 & 2,626 & 31 & 2,595 & 20,062 & 1,294 & 18,768 & - & - \\
\hline 2004 & 3,484 & 25 & 3,459 & 19,311 & 1,271 & 18,040 & - & - \\
\hline 2005 & 3,906 & 21 & 3,885 & 16,510 & 1,166 & 15,344 & - & - \\
\hline 2006 & 4,064 & 19 & 4,045 & 13,980 & 938 & 13,042 & - & - \\
\hline 2007 & 7,159 & 18 & 7,141 & 13,006 & 838 & 12,168 & - & - \\
\hline 2008 & 5,268 & 14 & 5,254 & 14,008 & 798 & 12,127 & 61 & 1,022 \\
\hline 2009 & 5,939 & 24 & 5,915 & 14,910 & 682 & 13,060 & 40 & 1,128 \\
\hline 2010 & 6,687 & 13 & 6,674 & 15,788 & 600 & 13,687 & 53 & 1,448 \\
\hline 2011 & 6,196 & 16 & 6,180 & 16,612 & 678 & 14,218 & 47 & 1,669 \\
\hline 2012 & 7,959 & 17 & 7,942 & 16,812 & 595 & 14,287 & 43 & 1,887 \\
\hline 2013 & 7,266 & 15 & 7,251 & 15,108 & 483 & 12,719 & 53 & 1,853 \\
\hline
\end{tabular}

